\title{
Hydrology and Simulation of Ground- Water Flow in the Aguadilla to Río Camuy Area, Puerto Rico
}

by Patrick Tucci and Myrna I. Martínez

\section{U.S. GEOLOGICAL SURVEY}

Water-Resources Investigations Report 95-4028

Prepared in cooperation with the

PUERTO RICO DEPARTMENT OF NATURAL AND ENVIRONMENTAL RESOURCES;

PUERTO RICO INDUSTRIAL DEVELOPMENT COMPANY;

PUERTO RICO AQUEDUCT AND SEWER AUTHORITY; and

PUERTO RICO INDUSTRIAL ASSOCIATION

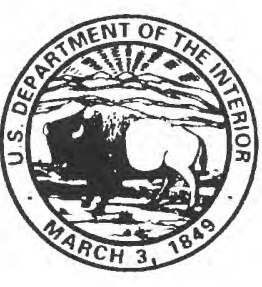




\section{U.S. DEPARTMENT OF THE INTERIOR BRUCE BABBITT, Secretary \\ U.S. GEOLOGICAL SURVEY \\ Gordon P. Eaton, Director}

The use of trade, product, industry, or firm names is for descriptive purposes only and does not imply endorsement by the U.S. Government.

For additional information write to: District Chief

U.S. Geological Survey Water-Resources Division GSA Center 651 Federal Drive, Suite 400-15 Guaynabo, PR 00965
Copies of this report can be purchased from: U.S. Geological Survey Books and Open-File Reports Section Denver Federal Center Box 25425, Mail Stop 517

Denver, CO 80225-0425 


\section{CONTENTS}

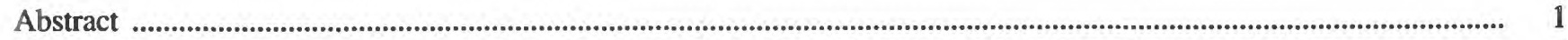

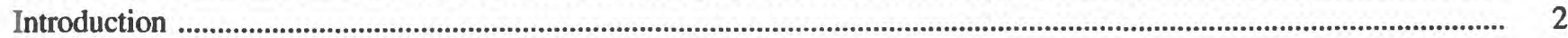

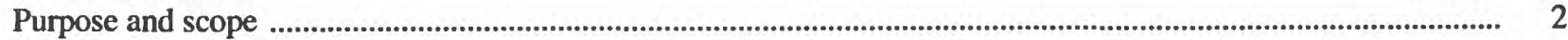

Description of study area .......................................................................................................................................... 5

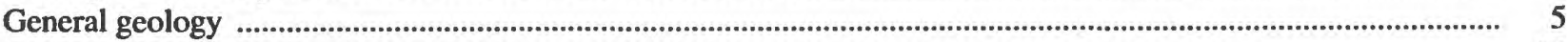

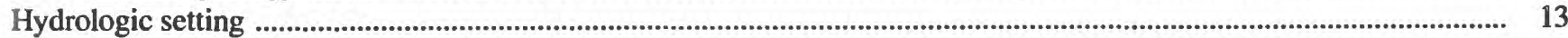

Surface-water hydrology ................................................................................................................................... 13

Ground-water hydrology ...................................................................................................................................... 16

Aquifer characteristics .................................................................................................................................... 16

Ground-water movement ........................................................................................................................... 21

Recharge and discharge ................................................................................................................................ 21

Simulation of ground-water flow .................................................................................................................................. 24

Model construction and boundary conditions ..................................................................................................... 24

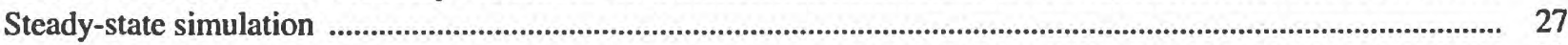

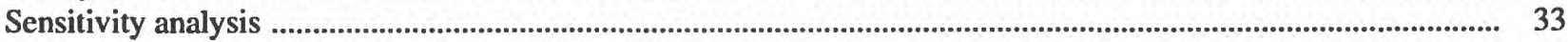

Model limitations and additional data needs ........................................................................................................ 36





\section{FIGURES}

1. Map showing location of the North Coast Province and study area ..................................................................... 3

2. Map showing the Aguadilla to Río Camuy study area........................................................................................ 4

3. Photograph showing sea cliffs near Quebradillas................................................................................................. 6

4. Map showing average-annual rainfall for northwestern Puerto Rico.............................................................. 7

5. Graphs showing average-annual rainfall at Isabela, Quebradillas, and Guajataca Dam, 1960-1990.................. 8

6. Graph showing average monthly rainfall at Isabela, Quebradillas, and Guajataca Dam, 1960-1990 .................. 9

7. Map showing generalized geology of northwestern Puerto Rico.......................................................................... 11

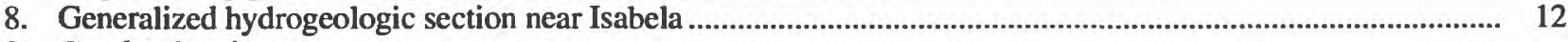

9-12. Graphs showing:

9. Average daily discharge for the Río Camuy near Bayaney and the Río Camuy near Hatillo ..................... 14

10. Flow-duration curves for the Río Camuy near Bayaney and the Río Camuy near Hatillo .......................... $\quad 15$

11. Average daily discharge for the Río Guajataca below Lago de Guajataca and the Río Guajataca near Quebradillas.

12. Flow-duration curves for the Río Guajataca below Lago de Guajataca and the Río Guajataca near Quebradillas

13-19. Maps showing:

13. Estimated saturated thickness of freshwater in the water-table aquifer.

14. Estimated average-annual water-table configuration and generalized direction of groundwater flow

15. Model grid and boundary conditions .............................................................................................. 25

16. Simulated water levels and differences from measured levels........................................................... 28

17. Calibrated transmissivity distribution of layer 1 ................................................................................. 30

18. Calibrated transmissivity distribution of layer 2 ................................................................................... 31

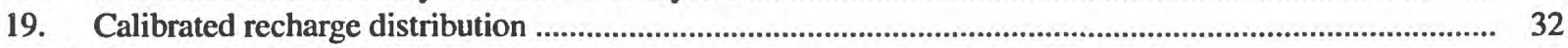

20. Graph showing model sensitivity to changes in recharge and transmissivity of layer 2 ....................................... 34

21. Graph showing model sensitivity to changes in river conductance and vertical leakance...................................... 35 


\section{TABLES}

1. Stratigraphic nomenclatures of the Middle Tertiary basin of the North Coast Province of Puerto Rico

2. Estimated transmissivity and hydraulic conductivity based on specific-capacity test data, northwestern Puerto Rico

3. Comparison of estimated and model-calculated water-budget components

3. Comparison of estimated and model-calculated water-budget components .....

CONVERSION FACTORS, ABBREVIATIONS, AND ACRONYMS

\begin{tabular}{|c|c|c|}
\hline Multiply & By & To obtain \\
\hline acre-foot (acre-ft) & 1,233 & cubic meter \\
\hline cubic foot $\left(\mathrm{ft}^{3}\right)$ & 0.02832 & cubic meter \\
\hline cubic foot per second $\left(\mathrm{ft}^{3} / \mathrm{s}\right)$ & 0.02832 & cubic meter per second \\
\hline foot (ft) & 0.3048 & meter \\
\hline foot per day $(\mathrm{ft} / \mathrm{d})$ & 0.3048 & meter per day \\
\hline gallon per minute per foot $[(\mathrm{gal} / \mathrm{min}) / \mathrm{ft}]$ & 0.2070 & liter per second per meter \\
\hline inch (in.) & 25.4 & millimeter \\
\hline mile (mi) & 1.609 & kilometer \\
\hline million gallons per day (Mgal/d) & 0.04381 & cubic meter per second \\
\hline square foot $\left(\mathrm{ft}^{2}\right)$ & 929.0 & square centimeter \\
\hline square foot $\left(\mathrm{ft}^{2}\right)$ & 0.09294 & square meter \\
\hline square foot per day $\left(\mathrm{ft}^{2} / \mathrm{d}\right)$ & 0.09290 & square meter per day \\
\hline square mile $\left(\mathrm{mi}^{2}\right)$ & 259.0 & hectare \\
\hline square mile $\left(\mathrm{mi}^{2}\right)$ & 2.590 & square kilometer \\
\hline
\end{tabular}

Degree Celsius $\left({ }^{\circ} \mathrm{C}\right)$ may be converted to degree Fahrenheit $\left({ }^{\circ} \mathrm{F}\right)$ by using the following equation:

$$
{ }^{\circ} \mathrm{F}=9 / 5\left({ }^{\circ} \mathrm{C}\right)+32 \text {. }
$$

Abbreviated water-quality units in report:

microsiemens per centimeter at $25^{\circ} \mathrm{C}(\mu \mathrm{S} / \mathrm{cm})$

\section{Acronyms used in report:}

Puerto Rico Department of Natural and Environmental Resources (PRDNER)

Puerto Rico Industrial Development Company (PRIDCO)

Puerto Rico Aqueduct and Sewer Authority (PRASA) 


\title{
Hydrology and Simulation of Ground-Water Flow in the Aguadilla to Río Camuy Area, Puerto Rico
}

\author{
ByPatrick Tucci and Myrna I. Martínez
}

\section{Abstract}

The aquifers of the Aguadilla to Río Camuy area, in the northwestern part of Puerto Rico, are the least developed of those on the north coast, and relatively little information is available concerning the ground-water system. The present study, which was part of a comprehensive appraisal of the ground-water resources of the North Coast Province, attempts to interpret the hydrology of the area within the constraints of available data.

The study area consists of an uplifted rolling plain that is 200 to 400 feet above sea level and a heavily forested, karst upland. The only major streams in the area are the Río Camuy and the Río Guajataca. Most water used in the area is obtained from Lago de Guajataca, just south of the study area, and ground-water use is minimal (less than 5 million gallons per day).

Sedimentary rocks of Tertiary age, mainly limestone and calcareous clays, comprise the aquifers of the Aguadilla to Río Camuy area. The rocks generally dip from 4 to 7 degrees to the north, and the total sedimentary rock sequence may be as much as 6,000 feet thick near the Atlantic coast.

Baseflows for the Río Camuy are 58 cubic feet per second near Bayaney and 72 cubic feet per second near Hatillo. The ground-water discharge to the Río Camuy between these stations is estimated to be 15 cubic feet per second, or 2.6 cubic feet per second per linear mile. The flow of the Río Guajataca is regulated by the Guajataca Dam at Lago de Guajataca. Ground-water discharge to the Río Guajataca between the dam and the coast is estimated to be about 17 cubic feet per second, based on the average ground-water discharge per linear mile estimated for the Río Camuy.

Both water-table and artesian aquifers are present in the Aguadilla to Río Camuy area; however, most ground water occurs within the water- table aquifer, which was the primary focus of this study. The top of the confining unit, below the water-table aquifer, generally is within the unnamed upper member of the Cibao Formation; however, it is within the Los Puertos Formation in the eastern part of the study area. The water-table aquifer primarily is composed of rocks of the Aymamón Limestone and the Los Puertos Formation. The estimated saturated thickness of the water-table aquifer ranges from zero at the southern limit of the aquifer to more than 600 feet south of Isabela.

\section{Hydraulic conductivity of the Aymamón} Limestone, based on specific-capacity test data for seven wells, ranges from about 1 to about 25 feet per day and averages 7.5 feet per day. Hydraulic conductivity of the Los Puertos Formation, based on specific-capacity test data for four wells, generally was less than 7 feet per day. The average hydraulic-conductivity value for both the Aymamón Limestone and the Los Puertos Formation, based on specific-capacity test data, is estimated to be about 6.0 feet per day. These hydraulic-conductivity values are much less than average values for the water-table aquifer reported for other parts of the North Coast Province. Transmissivity values, based on the average hydraulicconductivity value for the aquifer derived from specific-capacity tests, range from zero to about 4,000 feet squared per day; however, these values were adjusted upward during model calibration.

Ground water generally moves from the highlands in the south toward the sea to the north and west, and locally, to streams. A major groundwater divide extends from the southeastern corner of the study area to the northwest, and separates flow north and east into the study area from flow to the southwest toward the Río Culebrinas. Nearly all recharge to the aquifer is from infiltration of rainfall into the karst uplands. Discharge from the 
aquifer primarily occurs as leakage to streams and to the sea, and to a lesser degree as flow to wells.

A two-layer, three-dimensional, steadystate, numerical model was constructed to simulate ground-water flow in the water-table aquifer between Aguadilla and the Río Camuy area. A basic assumption of the model is that groundwater flow in the karst rocks of the study area can be approximated as flow through an isotropic, heterogeneous, porous medium. Recharge, at a rate of 22 inches per year, was simulated only over the southern highlands area.

Simulated water levels generally matched observed water levels, except at one well completed in a cavern that may reflect very localized flow conditions. The model-calculated water budget was about 72 cubic feet per second. This budget appears to be low, based on baseflow data reported for the Río Camuy and the Río Guajataca. Calibrated transmissivity values are higher than estimated values; however, the calibrated transmissivity values are similar to those estimated for adjacent areas to the east.

The results of the steady-state simulation are considered acceptable, given the general lack of hydrogeologic data and uncertainties in waterbudget components; however, the model should be considered as only partially, or incompletely, calibrated. Despite this consideration, model results indicate that the aquifer may be able to provide a significant amount of water for public supply and that additional ground-water development may be possible.

\section{INTRODUCTION}

The North Coast Province of Puerto Rico extends about 85 miles from the west coast near Aguadilla east to Loíza (fig. 1). The geologic formations that underlie the North Coast Province comprise some of the most important and productive aquifers on the island. The hydrogeologic system consists of a water-table aquifer that extends throughout the north coast and an underlying artesian aquifer that is of lesser areal extent. These aquifers supplied about $66 \mathrm{Mgal} / \mathrm{d}$ of water in 1985 for municipal, industrial, domestic, and agricultural use (H. Colon-Ramos, U.S. Geological Survey, written commun., 1989). Continued development and management of these aquifers is important in order to supply the continuing demand for water by Puerto Rico's increasing population and economic growth.
In order to provide a comprehensive appraisal of the ground-water resources of the North Coast Province, the U.S. Geological Survey (USGS), in cooperation with the Puerto Rico Department of Natural and Environmental Resources (PRDNER), the Puerto Rico Industrial Development Company (PRIDCO), the Puerto Rico Aqueduct and Sewer Authority (PRASA), and the Puerto Rico Industrial Association, began a long-term investigation in 1984 (Torres-González and Wolansky, 1984). The hydrogeologic study of the artesian aquifer was conducted in conjunction with the USGS Caribbean Islands Regional Aquifer-System Analysis Program (Gómez-Gómez, 1987). In order to facilitate study of the extensive water-table aquifer, the north coast was divided into four subareas: (1) San Juan Metropolitan area (the Río de la Plata to Loíza), (2) Manatí area (the Río Grande de Manatí to the Río Cibuco), (3) Arecibo area (the Río Camuy to the Río Grande de Manatí), and (4) Aguadilla area (Aguadilla to the Río Camuy, fig. 1). The Río Cibuco to the Río de la Plata area was previously described by Gómez-Gómez and Torres-Sierra (1988). This report documents the hydrology and simulation of groundwater flow in the water-table aquifer of the Aguadilla to Río Camuy subarea.

The aquifers of the Aguadilla to Río Camuy area are the least developed, in terms of pumpage, of the North Coast Province. Because of the great depths to water in much of the area and the availability of surface water from Lago de Guajataca (fig. 2) through a system of diversion canals, ground-water resources are relatively undeveloped and little information is available concerning the ground-water system.

\section{Purpose and Scope}

This report describes the hydrogeology and ground-water flow of the water-table aquifer of the Aguadilla to Río Camuy area. Three deep test holes were drilled to determine the subsurface geology near Isabela and Hatillo (fig. 2) and to determine variations in hydraulic head and specific conductance with depth at those sites (Rodríguez-Martínez and Hartley, 1994). Borehole-geophysical logs were obtained in 16 wells throughout the area to obtain subsurface geologic and hydrologic information; however, most of the wells were too shallow to provide much useful information. In addition, all available surface- and ground-water data were compiled and analyzed. These data were incorporated into a numerical ground-water flow model to test concepts of ground-water flow in the study area and to assess additional data needed for a more complete understanding of the water-table aquifer. 


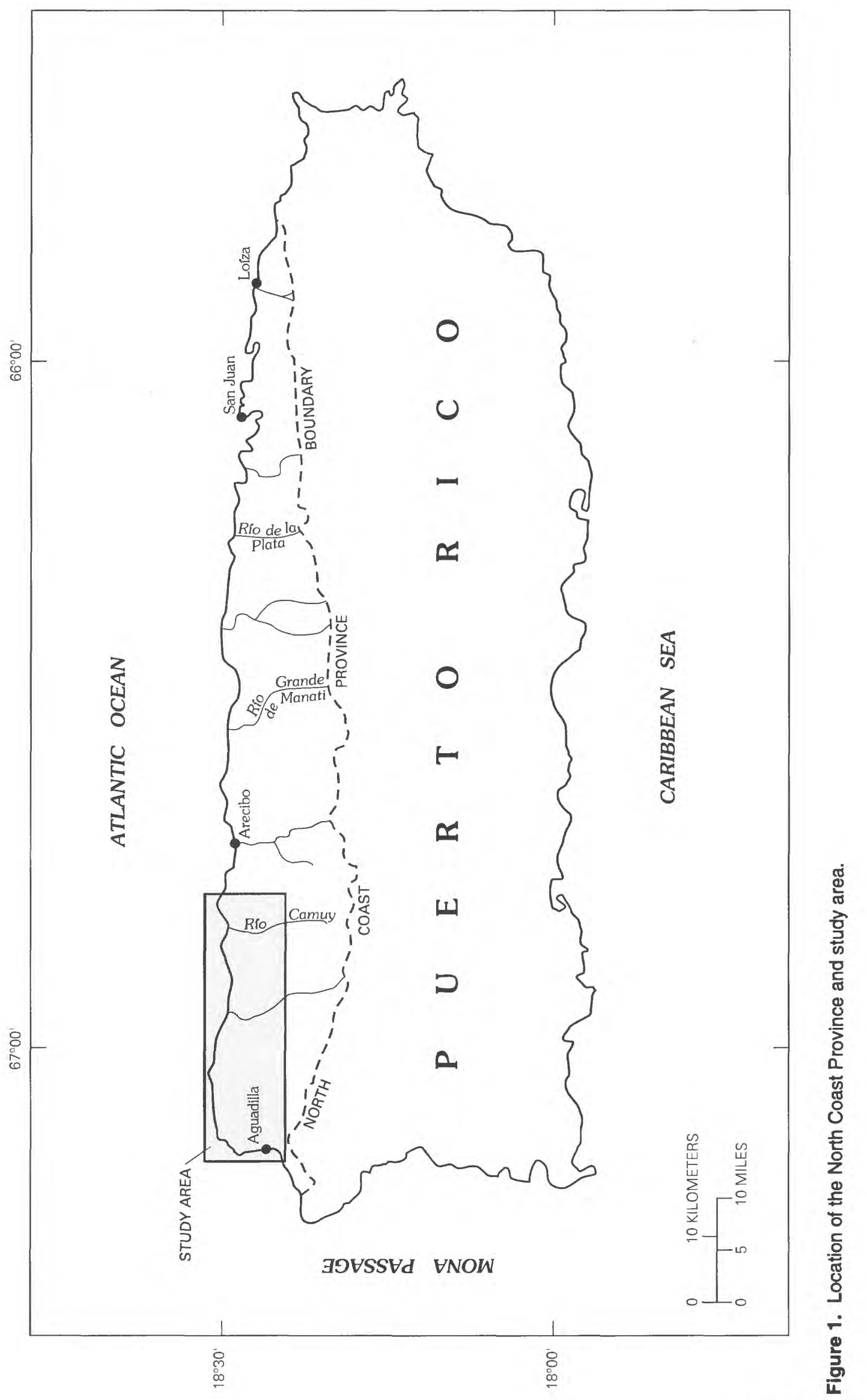

INTRODUCTION 


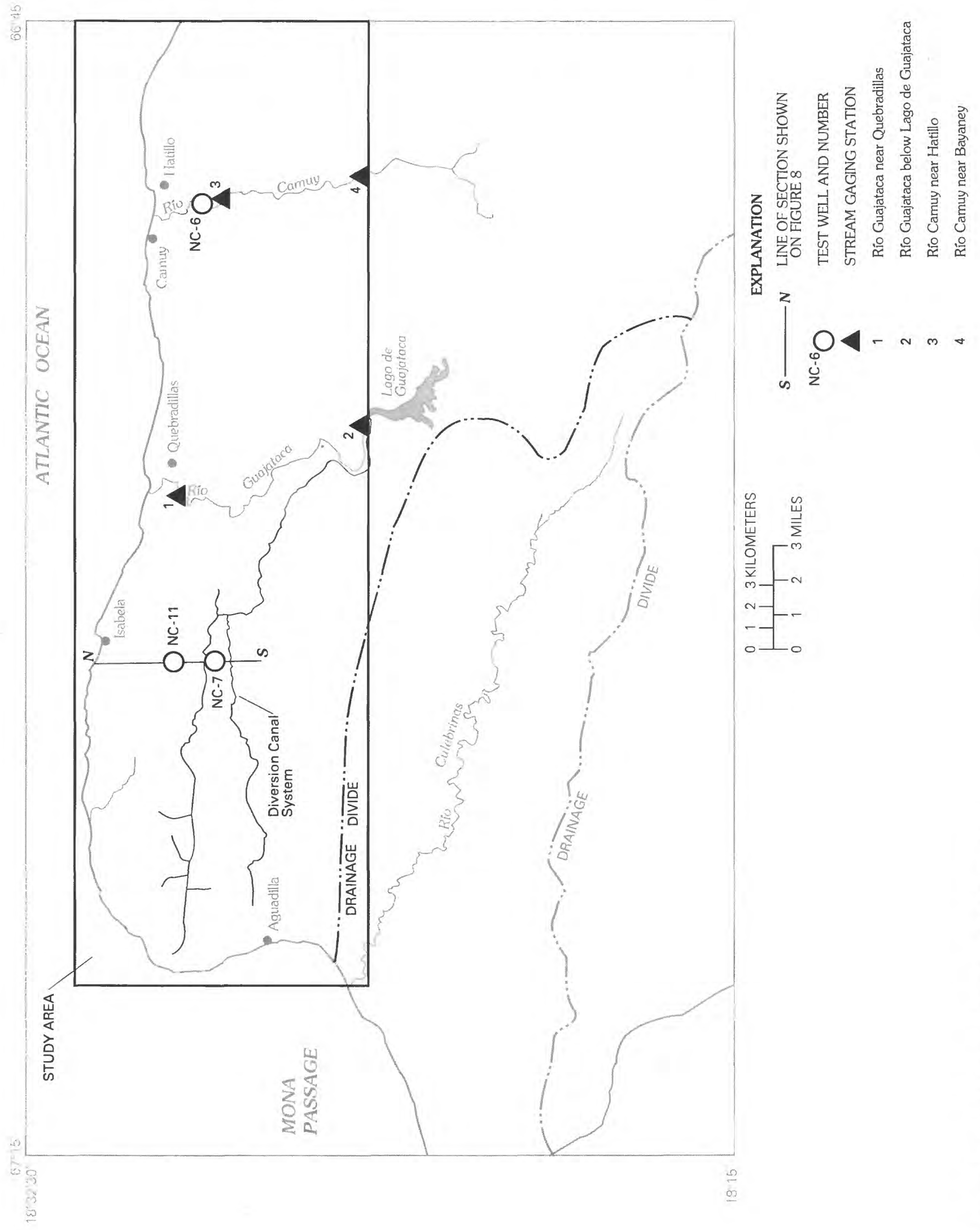

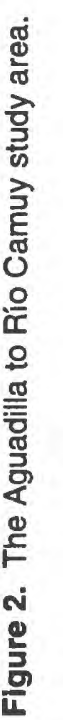




\section{Description of Study Area}

The Aguadilla to Río Camuy area covers an area of about $200 \mathrm{mi}^{2}$ in the westernmost part of the North Coast Province. The area is bordered by the Atlantic Ocean on the north, a steep escarpment on the south, and the Mona Passage on the west. The eastern boundary is a north-south line, about $5 \mathrm{mi}$ east of the Río Camuy, that parallels ground-water flow directions in that area. The largest municipality is Aguadilla, which had a population of about 59,000 in 1990 (U.S. Department of Commerce, 1991). About 75 percent of the population lives on farms and in rural communities, and about 25 percent lives in urban areas. Most of the land is agricultural, predominantly used as pasture for small family-owned farms. Most urban areas are located near the coast in the towns of Aguadilla, Isabela, Quebradillas, Camuy, and Hatillo (fig. 2).

The coast is characterized by cliffs that may locally rise more than $200 \mathrm{ft}$ above the sea (fig. 3). The southern boundary of the study area is an escarpment of several hundred feet that forms part of the drainage divide between the Rio Culebrinas to the south and the Atlantic Ocean to the north. The northern third of the area is a rolling plain that is 200 to $400 \mathrm{ft}$ above mean sea level. South of this plain is a rugged, heavily forested karst upland, typified by large, steep-sided sinkholes and tower karst.

Within the karst uplands and plains, there are very few surface-drainage features. The only major streams are the Rio Camuy to the east and the Rio Guajataca in the east-central part of the study area (fig. 2). The Río Camuy flows underground for a large part of its length and is the third largest underground stream in the world (Torres-Gonzalez, 1983; TorresGonzalez and others, 1984). The Río Guajataca and parts of the Río Camuy flow through steep, narrow gorges that are thought to be collapsed cave systems (Monroe, 1976). The only other significant surfacedrainage feature is Quebrada de los Cedros, an ephemeral stream in the extreme northwestern corner of the island. Other surface-drainage features are relatively short, draining to nearby sinkholes, and are dry during most of the year. Lago de Guajataca, just south of the study area (fig. 2), is a 40,000 acre-ft, manmade reservoir used for public-water supply.

The climate of the area is tropical, with an average-annual temperature of about $75^{\circ} \mathrm{F}$ (Heisel and others, 1983 , p. 4). Normal annual rainfall averaged between 60 and $80 \mathrm{in} / \mathrm{yr}$ in most of the study area from 1960 to 1990 (fig. 4). Total annual rainfall for this period ranged from 31 inches at Quebradillas to 104 inches at Guajataca Dam (fig. 5). Rainfall generally is greater in the karst uplands ( 70 to $80 \mathrm{in} / \mathrm{yr}$ ) than at the coast (less than $60 \mathrm{in} / \mathrm{yr}$ ). Rainfall generally is lower from January through March than during the rest of the year and greatest in May (fig. 6). Average monthly rainfall ranges from about 3 in. in February to about 9 in. in May (fig. 6). Monthly rainfall is greater in upland areas than in coastal areas during the wettest months.

\section{General Geology}

Sedimentary rocks of Tertiary age, and to a lesser extent Quaternary alluvium, comprise the aquifers of the Aguadilla to Río Camuy area. The following discussion is summarized from the detailed geologic descriptions of Monroe (1980) and RodríguezMartínez (1991). This report uses the stratigraphic nomenclature (table 1) of Seiglie and Moussa (1984), which is based on data from both the outcrop areas and the subsurface, rather than the nomenclature of Monroe (1980). The nomenclature of Seiglie and Moussa (1984) was adopted by Rodríguez-Martínez (1991) in his description of the hydrogeologic framework of the North Coast Province and is used in this report to relate to that framework. Most of the recent subsurface information was obtained from three deep core holes (NC-6, NC-7, and NC-11; fig. 2).

The sedimentary sequence, which consists mainly of limestone and calcareous clays, may be as much as 6,000 ft thick near the Atlantic coast (Monroe, 1980 , p. 8). These sedimentary rocks overlie volcanic rocks that comprise the mountains in the central part of the island. The sedimentary rock units in the study area, in ascending order, are the San Sebastián Formation, Lares Limestone, Cibao Formation, Los Puertos Formation, Aymamón Limestone, and the Quebradillas Limestone (figs. 7 and 8). Surficial deposits of Quaternary age, which consist of alluvium, blanket sands, marsh deposits, and beach deposits, locally overlie the Tertiary sediments (fig. 7).

The San Sebastian Formation primarily is a clay in the eastern part of the study area but contains gravel and cobbles in the western part. The San Sebastian ranges from 0 to about $300 \mathrm{ft}$ thick in the study area. The Lares Limestone consists primarily of a fine- to medium-grained limestone, although in the western part of the study area, the Lares grades laterally into clastic beds indistinguishable from the San Sebastián Formation. At well NC-11, the Lares appears to be absent from the section. The Lares Limestone is often solution-riddled and contains many of the island's major caves. The Lares ranges in thickness from 0 to about $1,000 \mathrm{ft}$ in the study area. The Cibao Formation is primarily an interbedded calcareous clay, with 


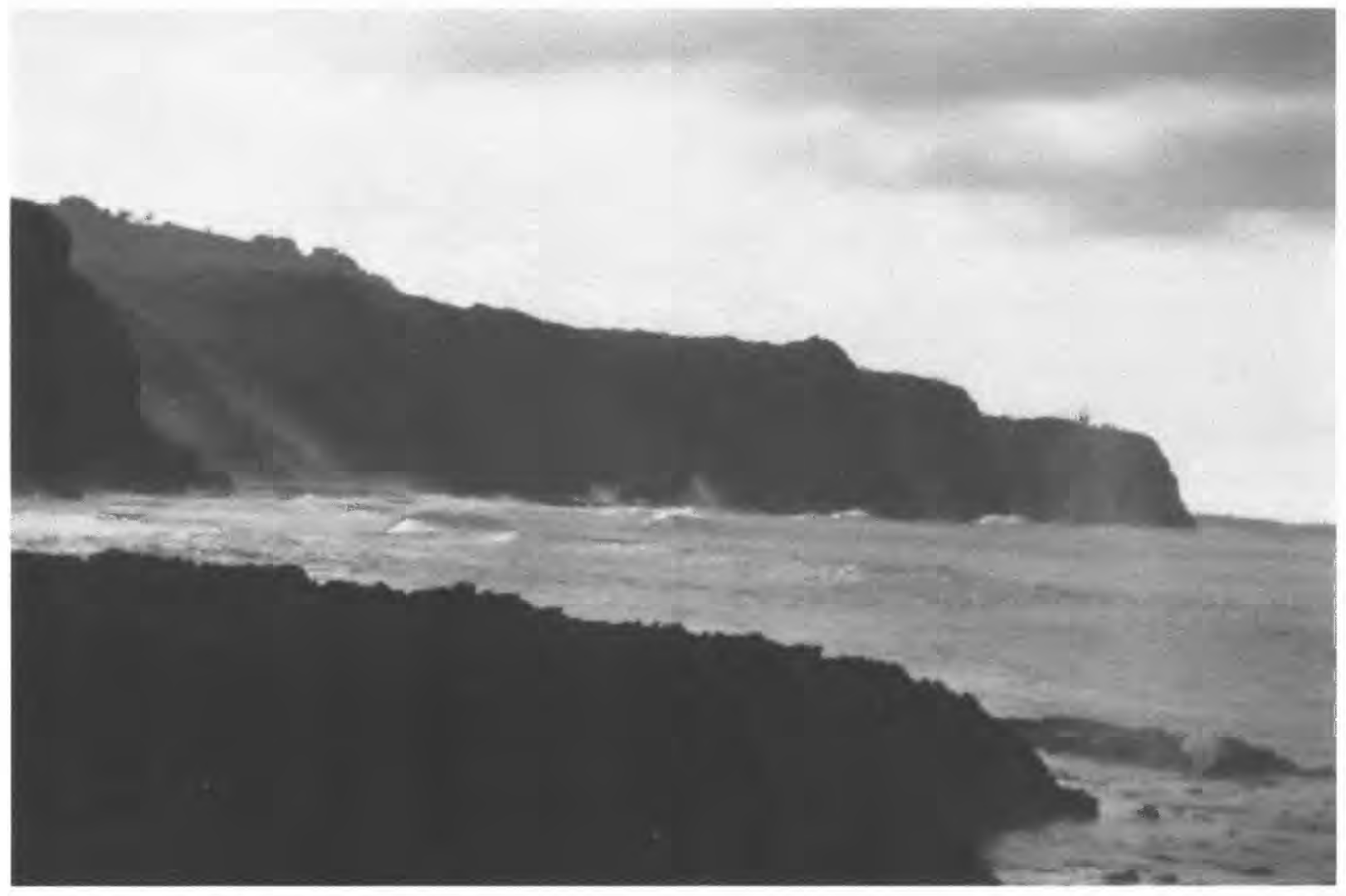

Figure 3. Sea cliffs near Quebradillas. 


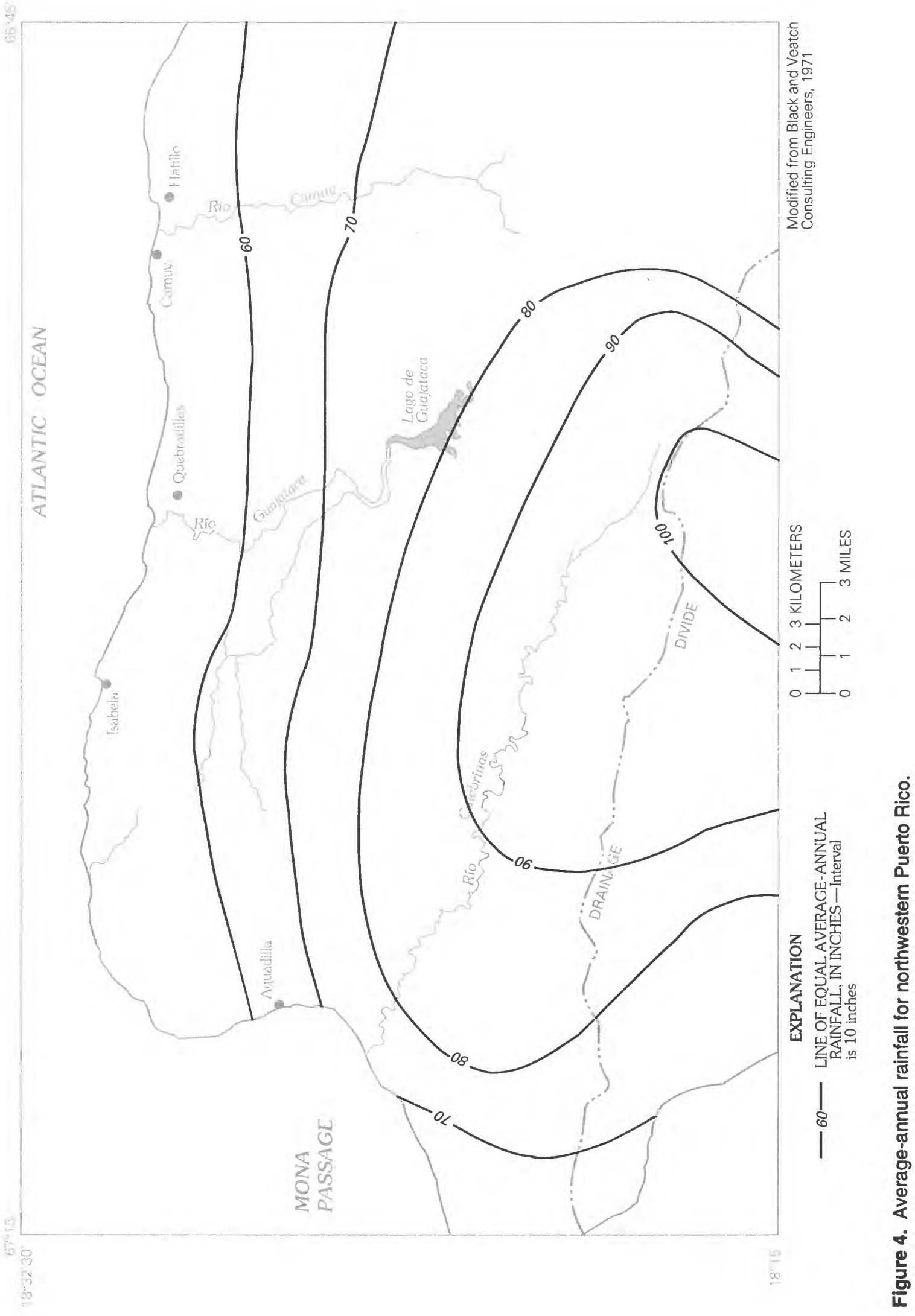



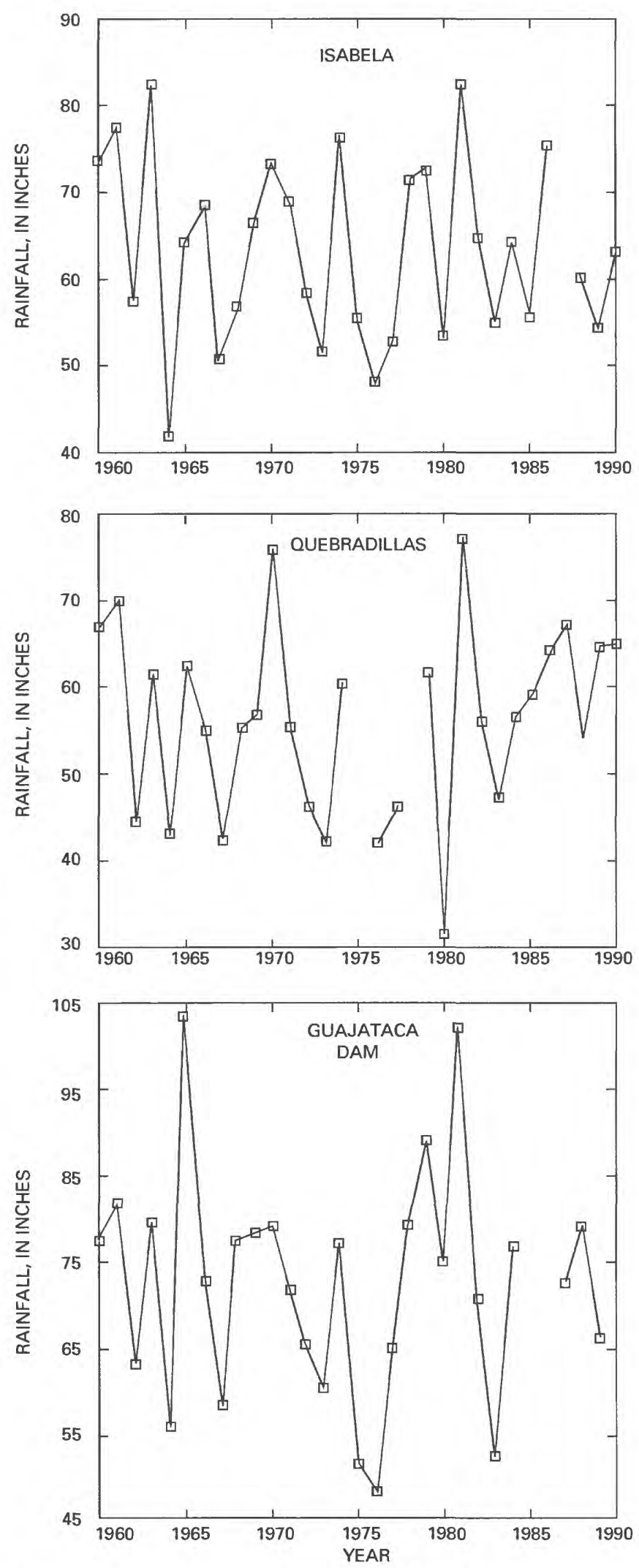

Figure 5. Average-annual rainfall at Isabela, Quebradillas, and Guajataca Dam, 1960-1990. 


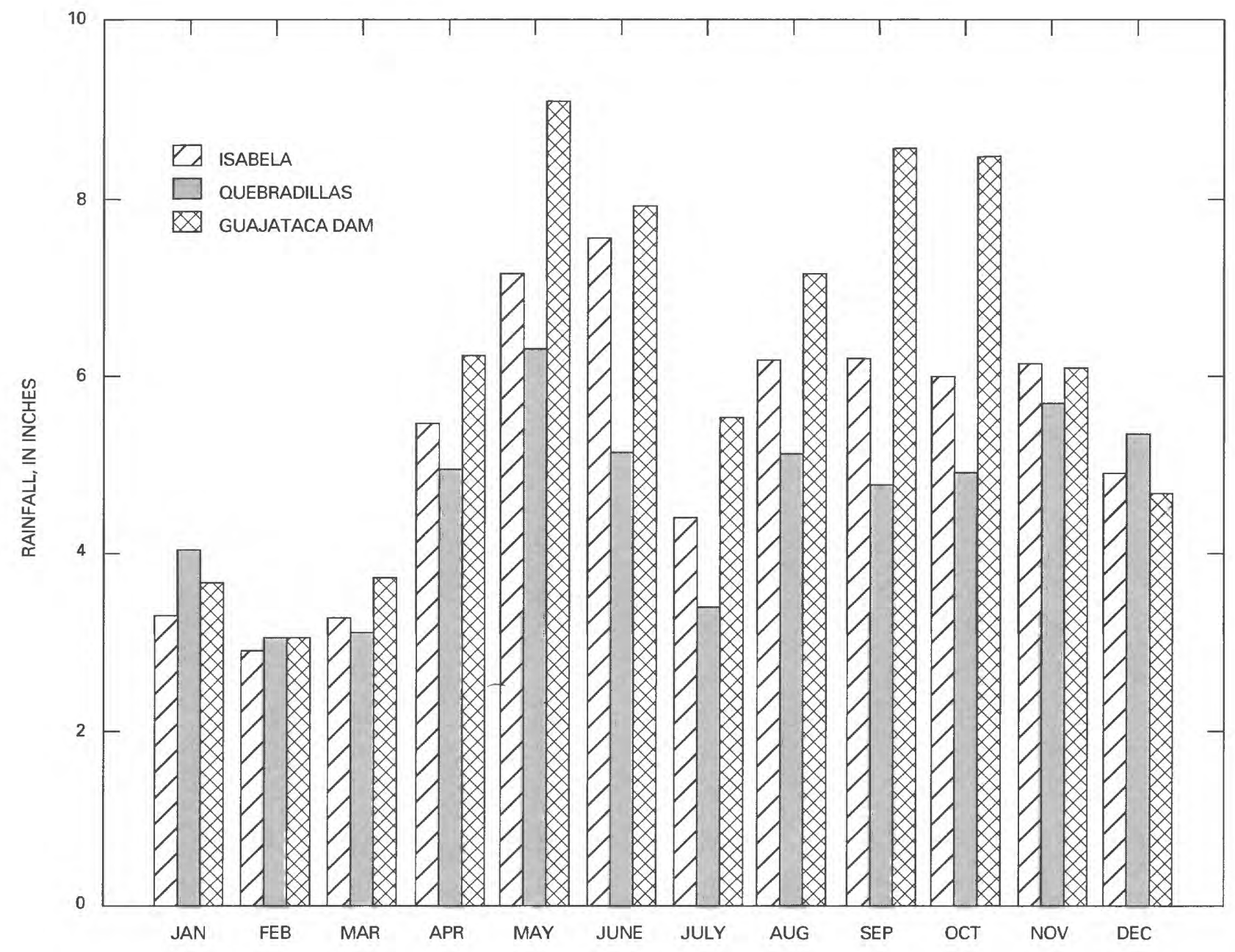

Figure 6. Average monthly rainfall at Isabela, Quebradillas, and Guajataca Dam, 1960-1990. 
Table 1. Stratigraphic nomenclatures of the Middle Tertiary basin of the North Coast Province of Puerto Rico (from Rodríguez/Martínez and Hartley, 1994)

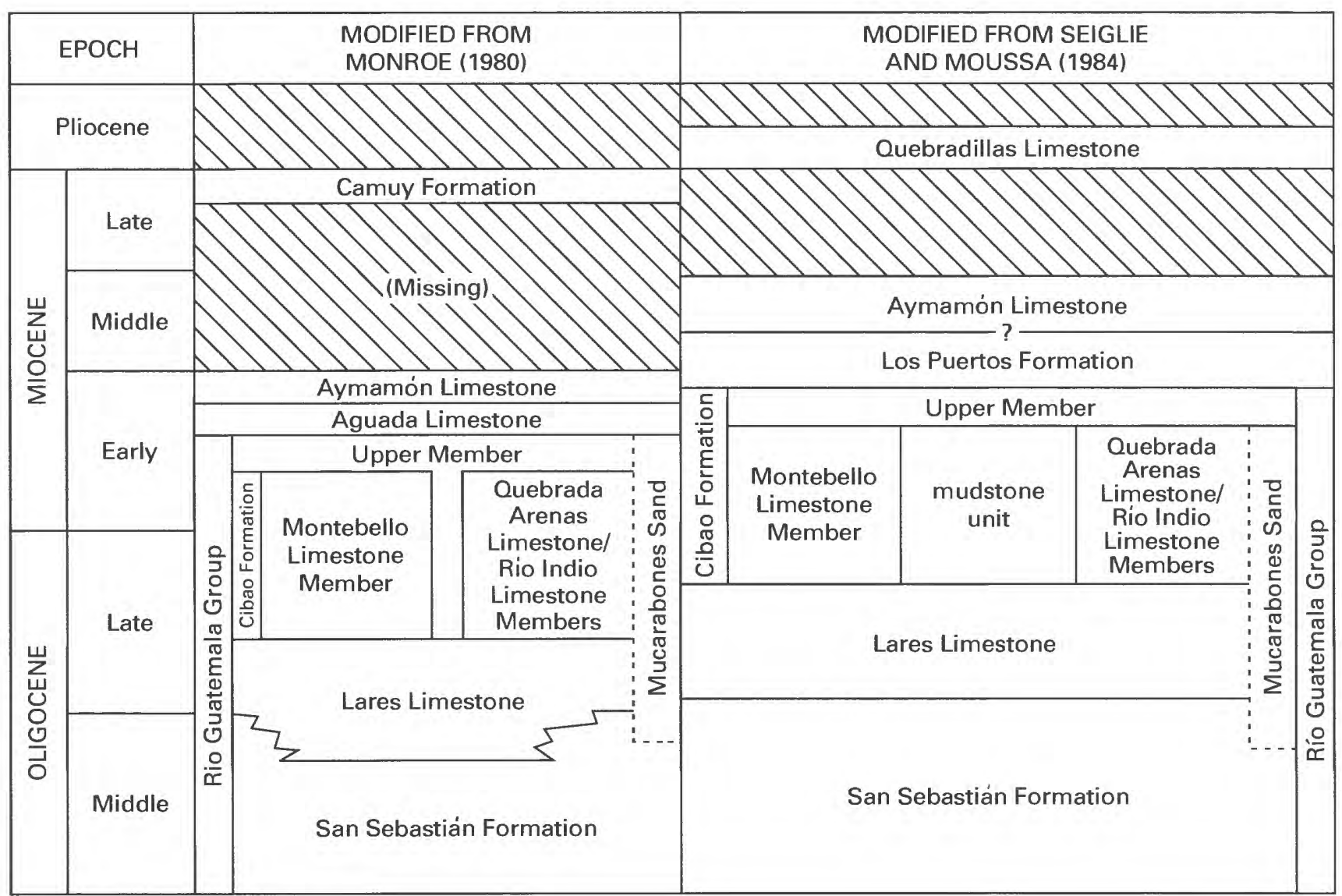




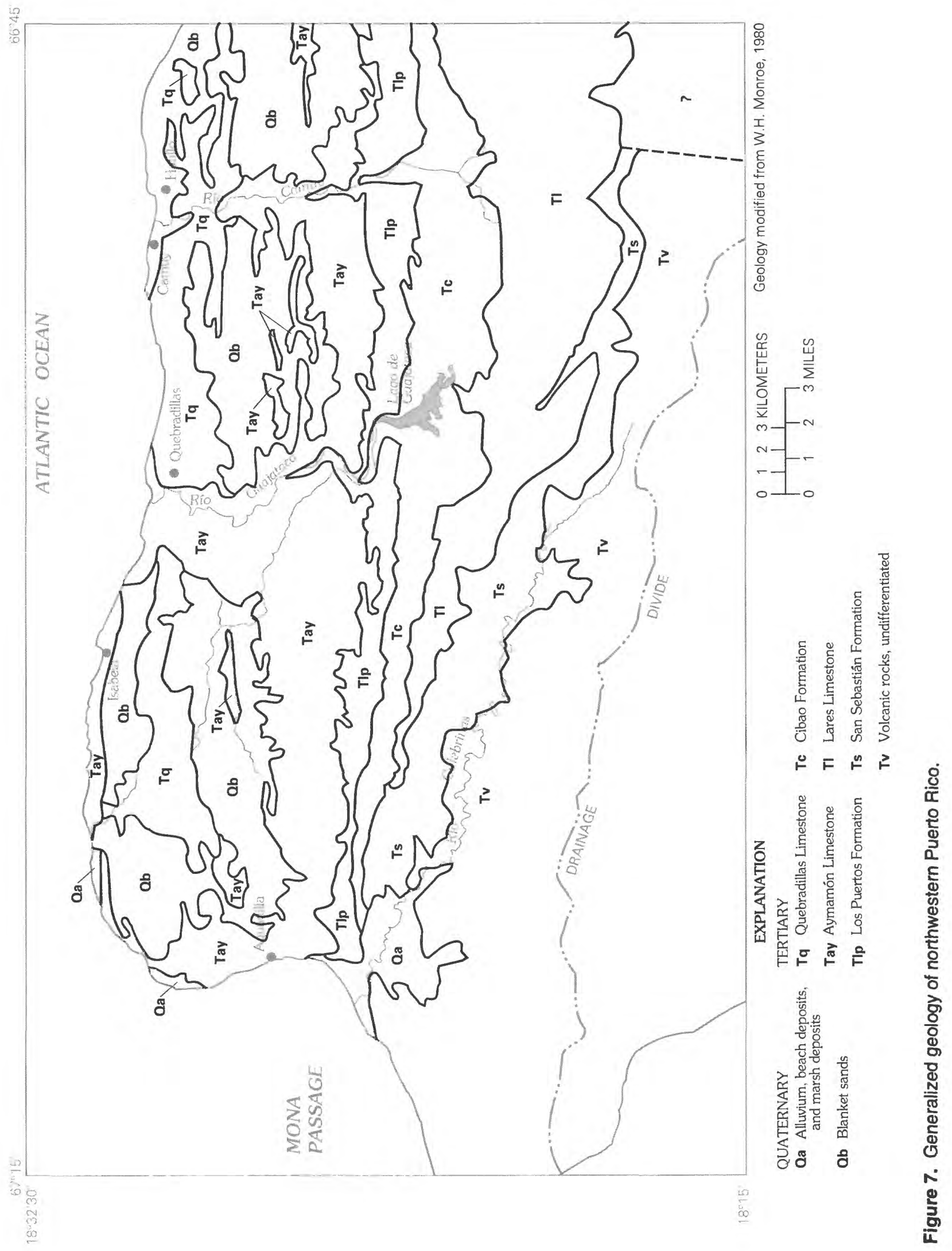




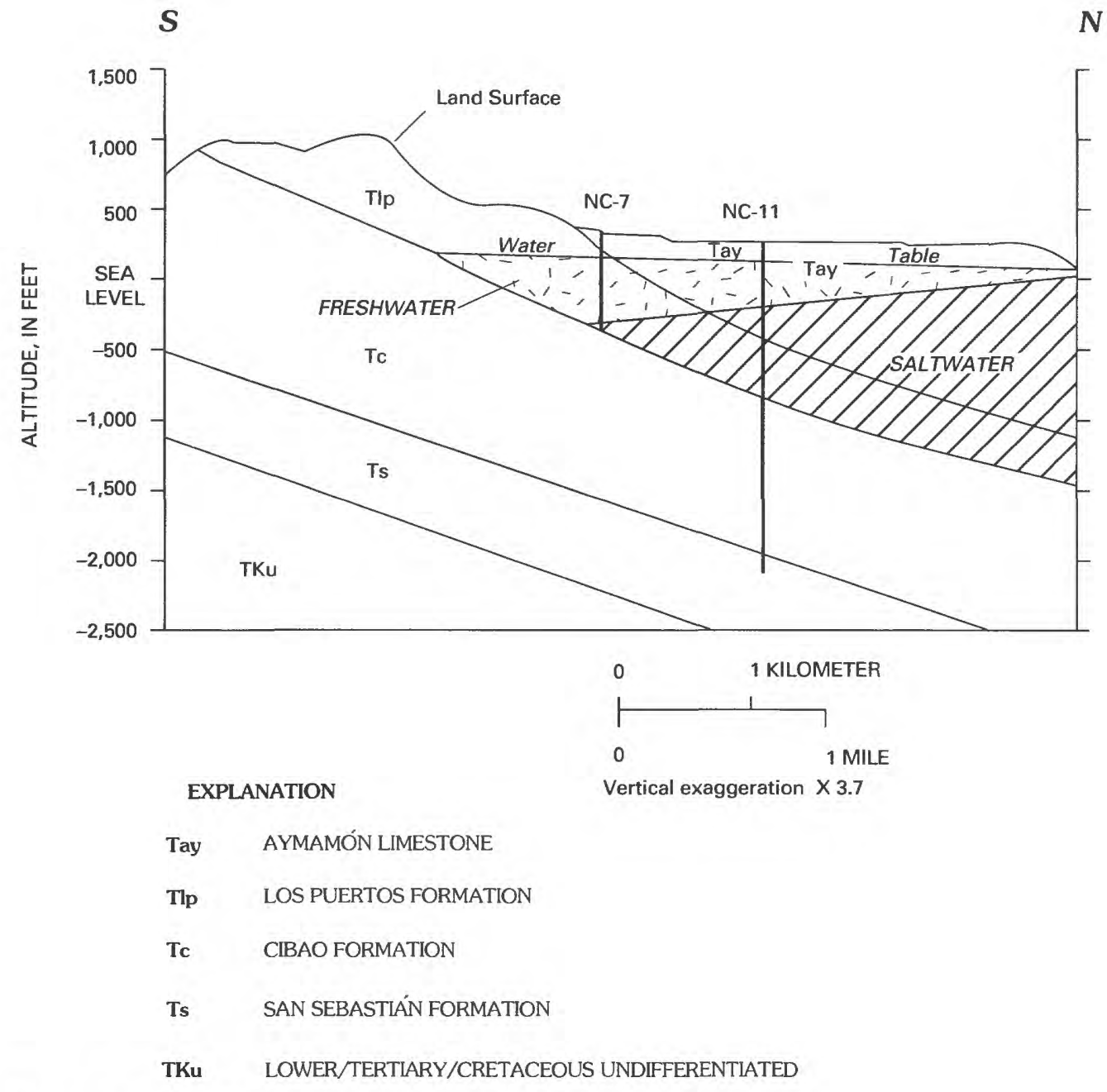

Figure 8. Generalized hydrogeologic section near Isabela. 
limestone, sandy clay, sand, and gravel. The Cibao contains significant amounts of sand and gravel near San Sebastián and contains limestone (Montebello Limestone Member of the Cibao Formation) in the lower part of the formation in the Rio Camuy area. The Cibao is about $650 \mathrm{ft}$ thick in the outcrop area, but it is $950 \mathrm{ft}$ thick at well NC-6. The Los Puertos Formation consists primarily of fossiliferous limestone. The Los Puertos commonly contains chalky beds in the lower part and nearly pure, indurated limestone in the upper part. The Los Puertos typically is about $300 \mathrm{ft}$ thick and is $340 \mathrm{ft}$ thick at well NC-6. The Aymamón Limestone is a very pure limestone that contains almost no clay or sand. Within the study area, the Aymamón is separated into two major members. The lower member has been extensively altered and recrystallized and is solution riddled. The upper member is predominately a chalky limestone. The Aymamón ranges in thickness from $600 \mathrm{ft}$ in outcrops to more than $1,000 \mathrm{ft}$ at well NC-6. The Quebradillas Limestone is predominately limestone but contains some sand. The lower parts of the Quebradillas consist of chalk or chalky limestone and contains appreciable amounts of quartz sand. The upper part of the Quebradillas consists of chalk, limestone, and calcareous sandstone. The thickness of the Quebradillas ranges from 0 to less than $100 \mathrm{ft}$. At well NC-6, the Quebradillas is about $85 \mathrm{ft}$ thick.

The rocks generally strike to the west and dip from 4 to 7 degrees to the north. The dips are reversed slightly near Isabela along a continuation of a northwest-trending anticline and syncline northeast of the municipality of Isabela (Monroe, 1969). No other major structural features have been recognized within the study area.

\section{HYDROLOGIC SETTING}

The hydrologic setting of the Aguadilla to Río Camuy area appears to be complex but is not well understood. Continuous streamflow and groundwater-level data were not obtained until 1985 in most of the area. Except for the two main streams, there is little surface drainage. Most drainage in the area appears to be underground and is probably continuous with the water-table aquifer. Because ground water is only a minor source of water for the area (S. GuzmánRíos, U.S. Geological Survey, written commun., 1991), water-supply wells and the information that can be obtained from them are sparse. The following summary discussions of surface- and ground-water hydrology are based on the relatively sparse hydrologic data available for the area.

\section{Surface-Water Hydrology}

The Aguadilla to Río Camuy area is typical of karst areas and is characterized by few surface-water drainage features. The Río Camuy and the Río Guajataca are the only two perennial streams. Quebrada de los Cedros, the only other surface-drainage feature of significant size, is an ephemeral stream. The drainage areas of these streams are unknown because of the contribution of karstic subsurface drainage.

The Río Camuy is unregulated, and continuous streamflow data have been collected at two stations (the Río Camuy near Bayaney and the Río Camuy near Hatillo; fig. 2) since 1984. Mean annual streamflow for the period 1985 to 1990 of the Rio Camuy was $110 \mathrm{ft}^{3} / \mathrm{s}$ near Bayaney and $177 \mathrm{ft}^{3} / \mathrm{s}$ near Hatillo (Curtis, and others, 1991, p. 62-64). Maximum reported flows during this period were 6,450 and $10,500 \mathrm{ft}^{3} / \mathrm{s}$ near Bayaney and Hatillo, respectively (Curtis, and others, 1991, p. 62-64). Streamflow hydrographs for these two stations are shown on figure 9.

Flow-duration curves are cumulative frequency curves that show the percent of time during which specified discharges of streams were equaled or exceeded in a given period of time (Searcy, 1959, p. 1). Comparison of flow-duration curves can provide valuable insights into the drainage characteristics of different streams or of different reaches of the same stream. Steep curves are indicative of a high degree of runoff in the drainage basin, but flat curves are indicative of a high degree of surface or subsurface storage in the basin.

Baseflows were estimated for the Río Camuy near Bayaney and Hatillo using a method proposed by the Institute of Hydrology $(1980 \mathrm{a}, \mathrm{b})$. In this method, the days of the water year (October 1 through September 30) are divided into 5-day increments, and the minimum flow for each 5-day increment is identified. If 0.9 times a minimum is less than both adjacent minimums, the minimum is a turning point of the baseflow hydrograph. Straight lines are drawn between turning points on semilog paper; the area beneath this line is an estimate of the volume of baseflow for the period. This method has been incorporated into a computer program (K.L. Wahl, U.S. Geological Survey, written commun., 1994) that was used to estimate baseflows. Estimated baseflow for the period 1985-90 was about $58 \mathrm{ft}^{3} / \mathrm{s}$ near Bayaney and about $72 \mathrm{ft}^{3} / \mathrm{s}$ near Hatillo. These values approximately correspond to the 60 percent flow-duration value (fig. 10 ) for those stations. The difference in baseflow between the stations is $14 \mathrm{ft}^{3} / \mathrm{s}$ and is indicative of the average-annual ground-water contribution to streamflow (about 

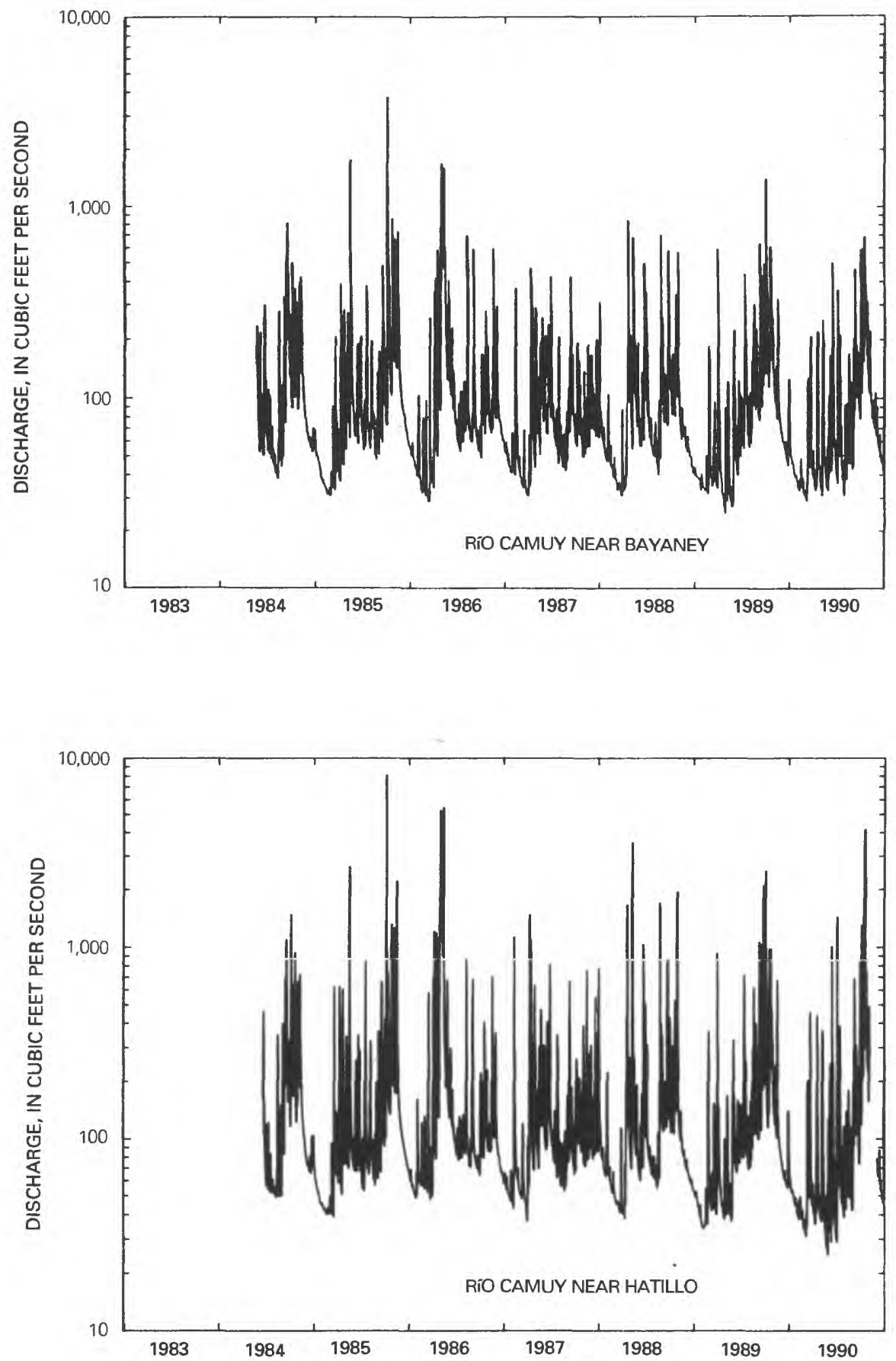

Figure 9. Average daily discharge for the Río Camuy near Bayaney and the Río Camuy near Hatillo. 


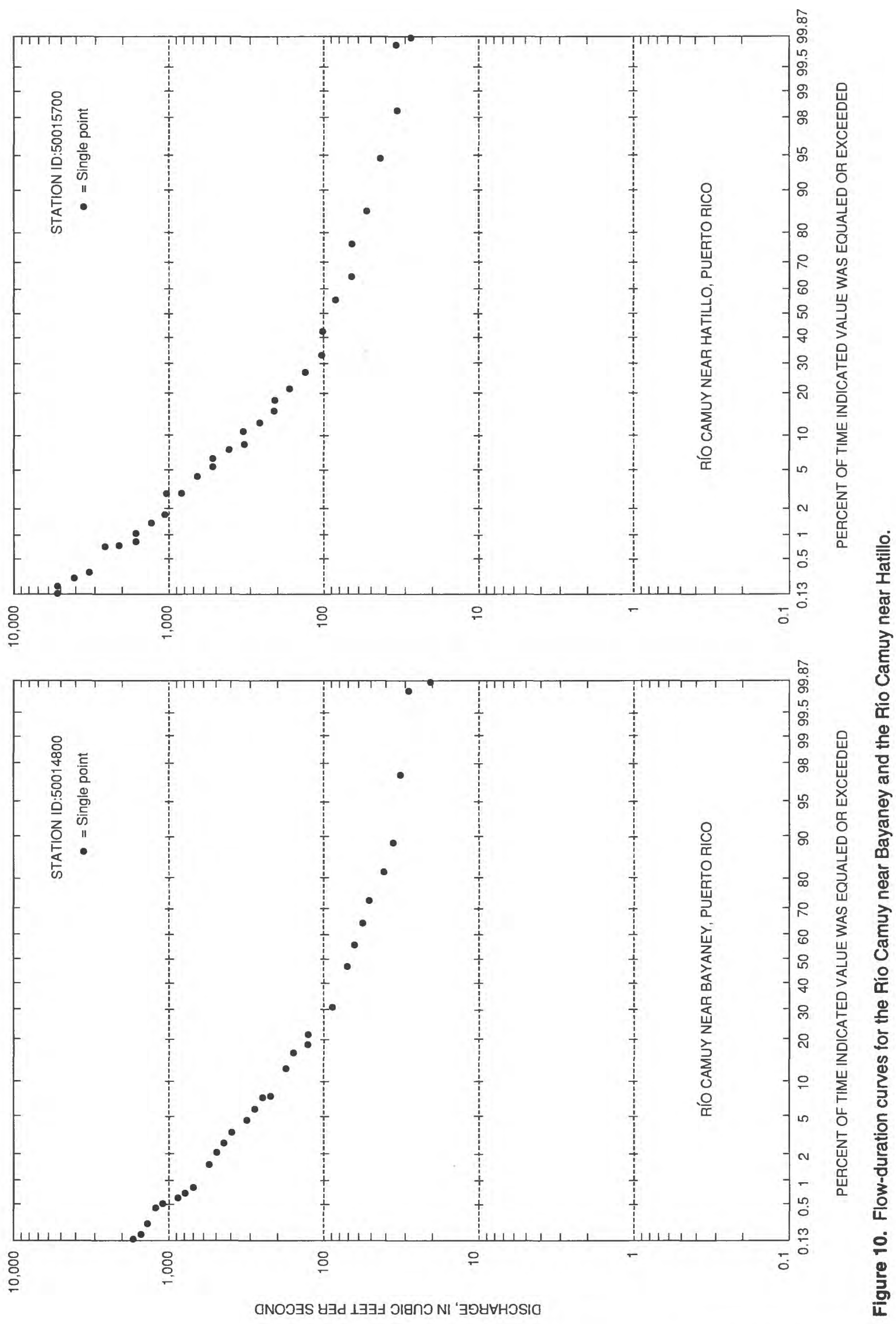


$2.6 \mathrm{ft}^{3} / \mathrm{s}$ per linear mile between Bayaney and Hatillo) from 1985-90.

The flow of the Río Guajataca is regulated by the Guajataca Dam, forming Lago de Guajataca. Continuous streamflow data were collected from 1984 through 1989 at stations below the Guajataca Dam and near Quebradillas (fig. 2). Mean annual streamflows for this period were about $34 \mathrm{ft}^{3} / \mathrm{s}$ below the Guajataca Dam and about $92 \mathrm{ft}^{3} / \mathrm{s}$ near Quebradillas (fig. 11). Maximum reported flows were 1,350 and $6,200 \mathrm{ft}^{3} / \mathrm{s}$ at stations below the Guajataca Dam and near Quebradillas, respectively.

The shape of the flow-duration curves for the Río Guajataca is different than those for the Río Camuy, reflecting the influence of the regulation of outflow from Lago de Guajataca. These curves (fig. 12) cannot be used to discuss the natural drainage characteristics of the Río Guajataca because of this regulation of flow. The contribution of ground-water flow to Río Guajataca can be estimated, however, by applying information obtained for the Río Camuy. Because geologic units and hydraulic gradients are similar for the two streams, the average ground-water contribution (2.6 $\mathrm{ft}^{3} / \mathrm{s}$ per linear mile) obtained for the Río Camuy may be applied to the Río Guajataca between Lago de Guajataca and Quebradillas. Using this method, the average-annual ground-water contribution from 1985 to 1990 was estimated to be about $17 \mathrm{ft}^{3} / \mathrm{s}$.

Water is diverted from Lago de Guajataca to a diversion canal for public supplies of the municipalities on the northwestern part of Puerto Rico. The median value of this diversion from 1985 to 1990 was about $14 \mathrm{ft}^{3} / \mathrm{s}$, based on median discharge at streamflow stations upstream and downstream of Lago de Guajataca. Estimates from PRASA indicate that about 4 to $6 \mathrm{ft}^{3} / \mathrm{s}$ of this diversion is lost, mainly in the first few miles from Lago de Guajataca, due to seepage from this canal (Ing. J. Lizasoaín, Puerto Rico Aqueduct and Sewer Authority, oral commun., 1991). The water lost may provide an additional source of recharge to the watertable aquifer.

\section{Ground-Water Hydrology}

Most ground water in the Aguadilla to Río Camuy area occurs within the water-table aquifer that extends throughout the North Coast Province. An underlying artesian aquifer, which is an important source of ground water in north-central Puerto Rico, becomes fragmented and less productive west of Arecibo (Rodríguez-Martínez, 1991, p. 15; Ward and others, 1991). Several zones of relatively low yield contained ground water under confined conditions below the water-table aquifer at wells NC-6 and NC-11 Rodríguez-Martínez and Hartley, 1994). The artesian aquifer will not be considered further in this report.

The water-table aquifer extends from the watertable surface to the top of the freshwater/saline-water interface near the coast, and to the top of the first underlying confining unit in the rest of the study area. The freshwater/saline-water interface is not a sharp interface in the study area but rather a transition zone from about 75 to $115 \mathrm{ft}$ thick, of relatively freshwater (less than $500 \mu \mathrm{S} / \mathrm{cm}$ ) to saline water (greater than $15,000 \mathrm{uS} / \mathrm{cm})$. The top of the underlying confining unit generally is within the unnamed upper member of the Cibao Formation, a calcareous marl unit. At well NC-6, however, the top of the underlying confining unit is a claystone interval within the Los Puertos Formation.

The water-table aquifer primarily is comprised of rocks of the Aymamón Limestone and the Los Puertos Formation, although some localized alluvial deposits are present at the uppermost part of the aquifer near the mouth of the Río Camuy. The Aymamón is the most important part of the aquifer in the north because the Los Puertos lies below the freshwater/saline-water interface near the coast. In the south, the Los Puertos is the most important part of the aquifer because the Aymamón is unsaturated in that area. The Quebradillas Limestone is unsaturated throughout the study area.

The estimated freshwater-saturated thickness of the water-table aquifer ranges from zero at the southern limit of the aquifer to over $600 \mathrm{ft}$ south of Isabela (fig. 13). These estimates are based on projecting the slope of the base of the aquifer and the base of freshwater, as determined at wells NC-6 and NC-11, to the north and south, and subtracting the basal elevation from the elevation of the average water-table surface at selected points. Because of the scarcity of data points, these thicknesses must be considered speculative.

\section{Aquifer Characteristics}

Very little is known of the aquifer characteristics of the water-table aquifer because no rigorous aquifer tests have been conducted within the study area. Estimates of hydraulic conductivity have been made, using methods described by Theis and others (1963), based on specific-capacity test data obtained from 14 PRASA public-supply wells.

Of the 14 wells tested, 2 were completed within alluvial deposits, 8 were within the Aymamón Limestone, and 4 were within the Los Puertos Formation (table 2). One well (El Rey \#2), located in the central part of the study area, is completed in a cavern in the Aymamón Limestone, and has an anomalously high 

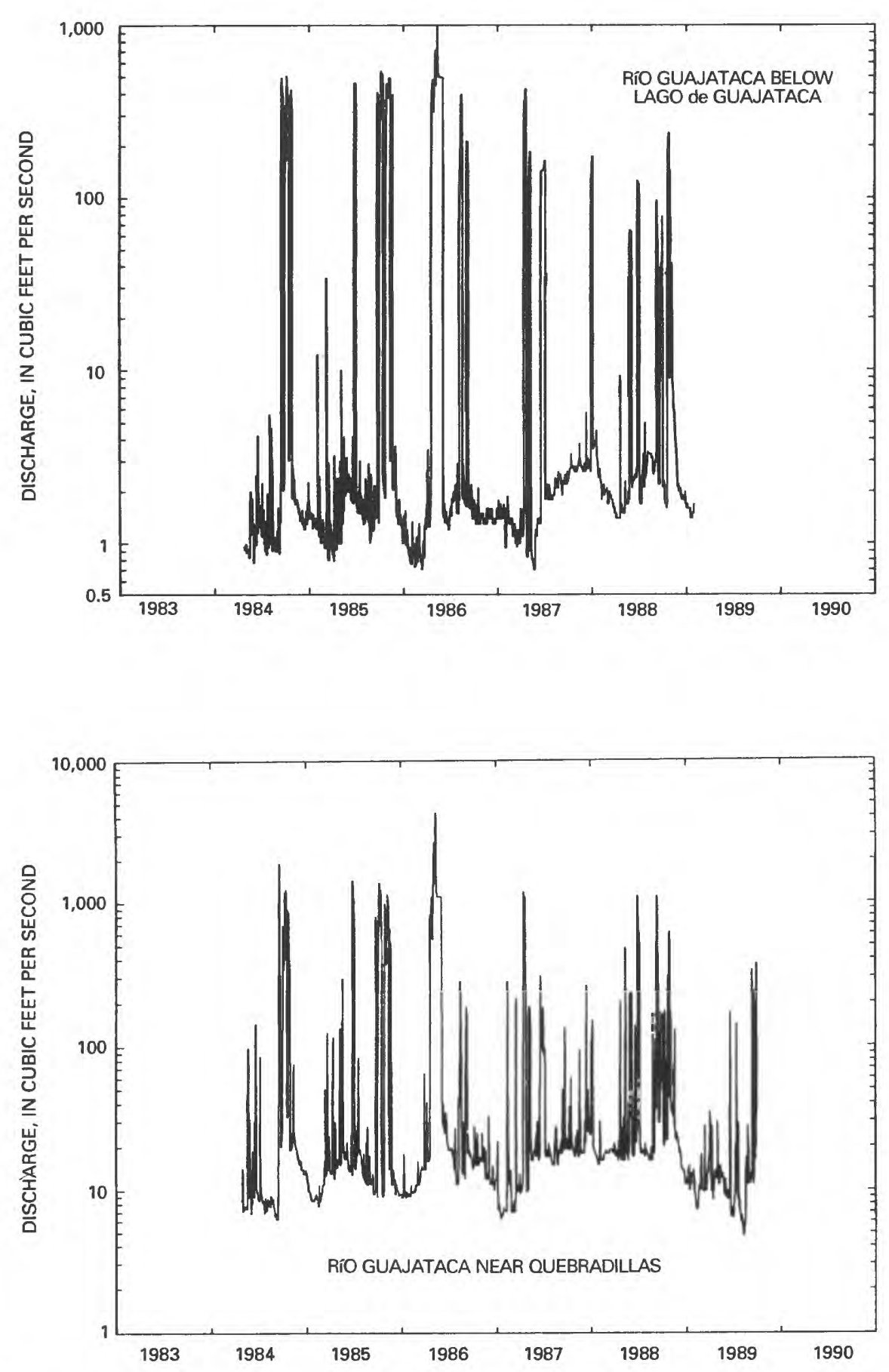

Figure 11. Average daily discharge for the Rio Guajataca below Lago de Guajataca and the Rio Guajataca near Quebradillas. 


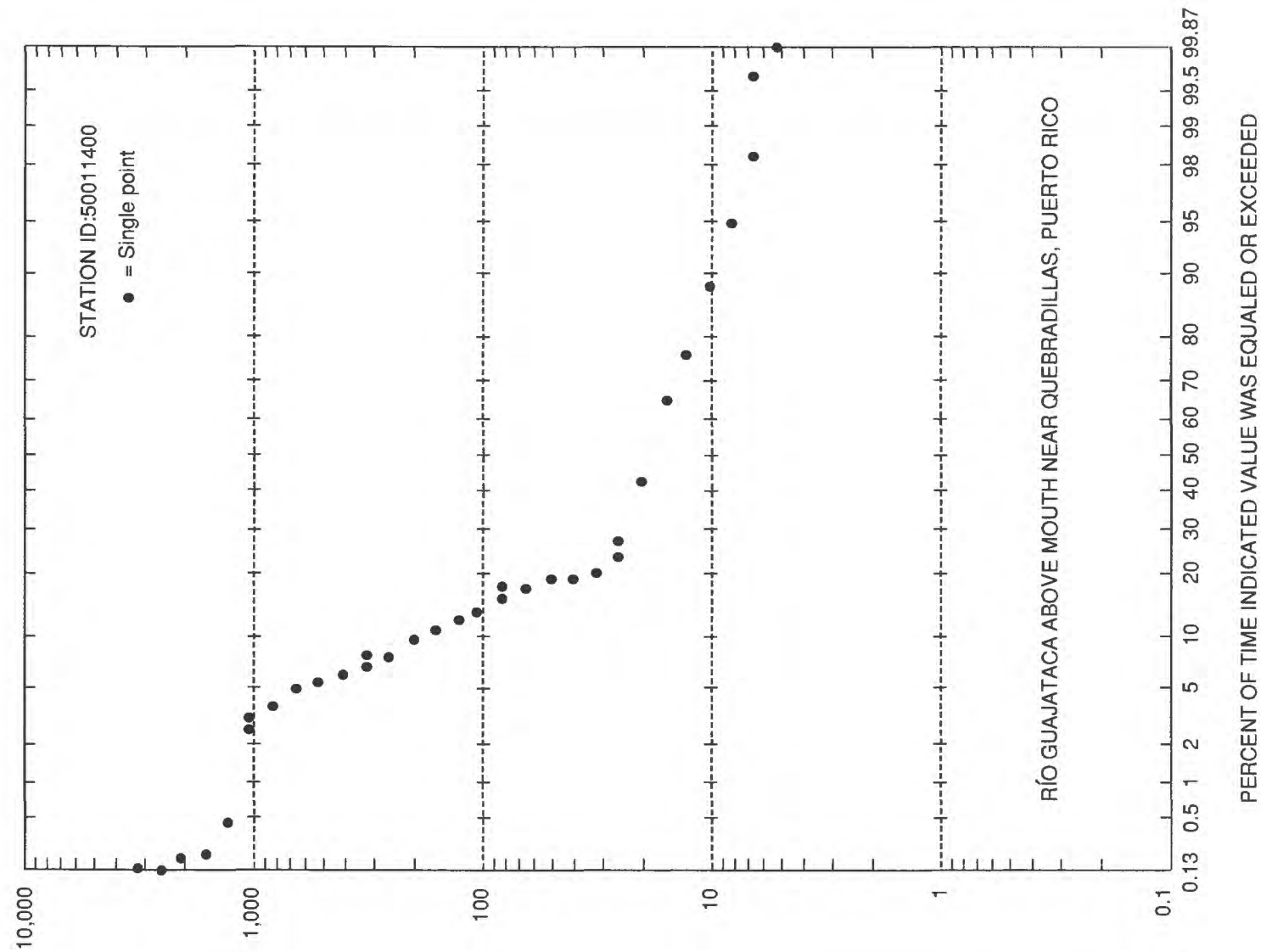

\%

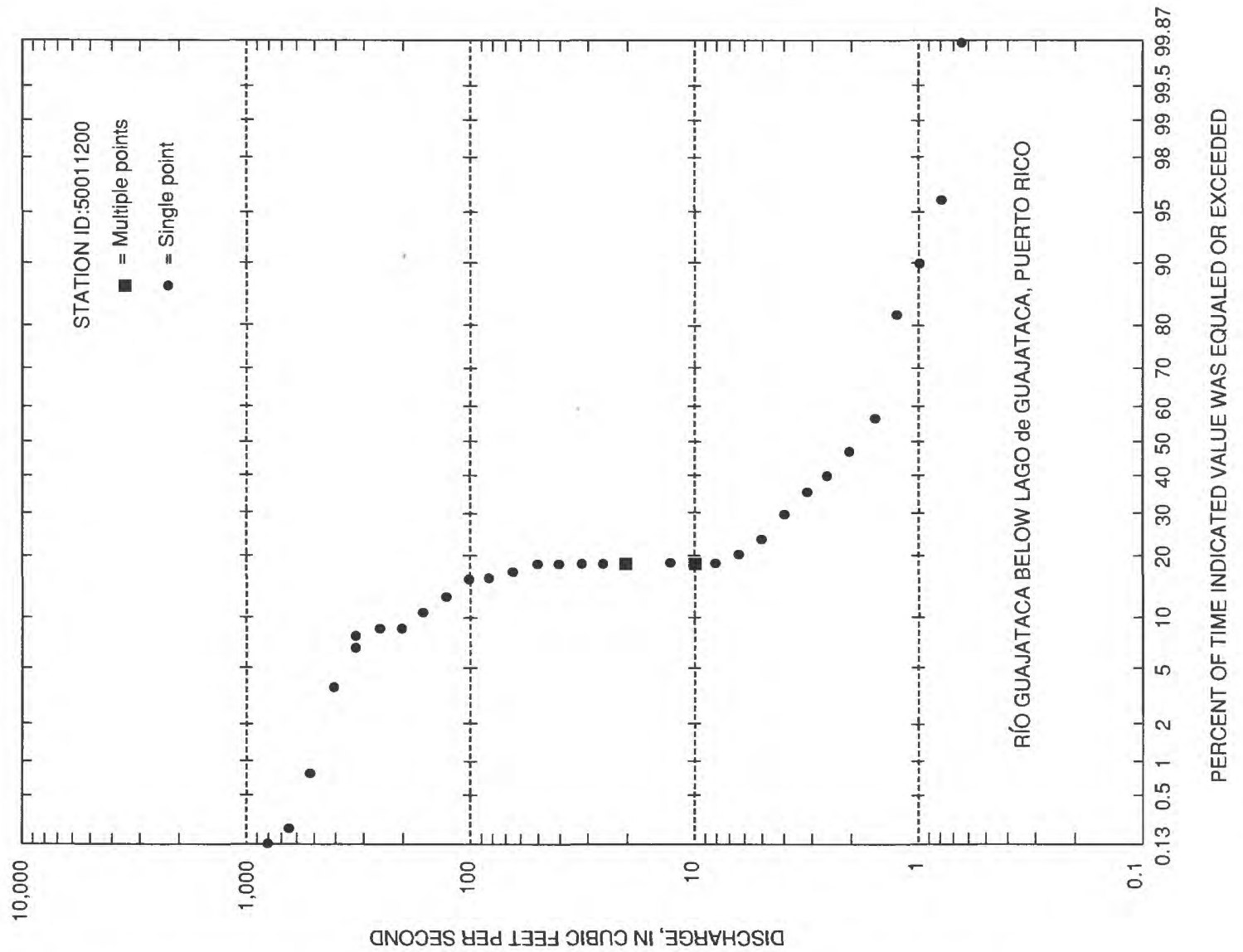

要 


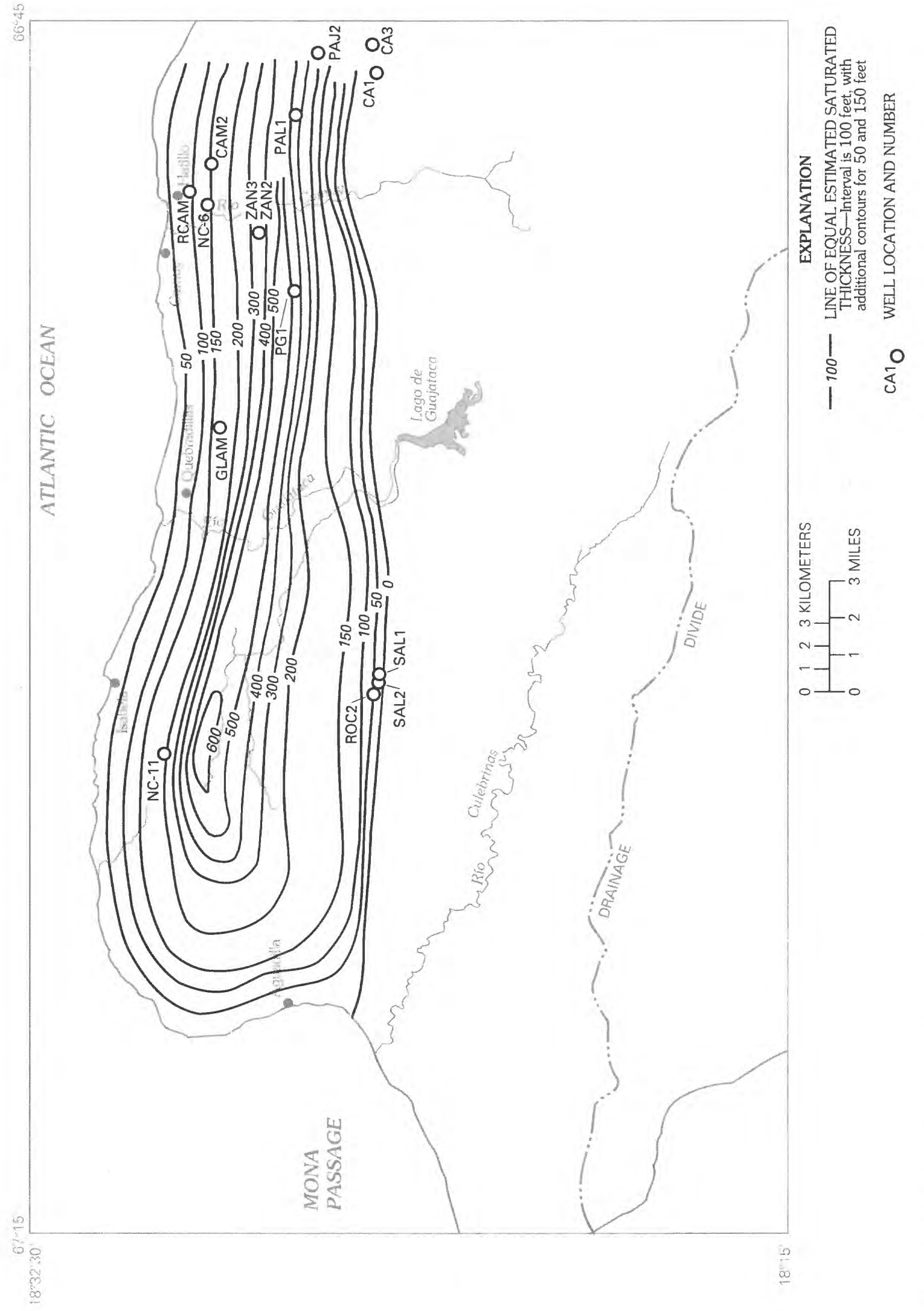

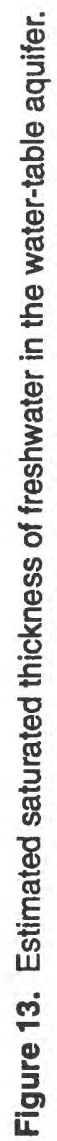


specific capacity (greater than 200 ( $\mathrm{gal} / \mathrm{min}$ )/ft of drawdown). Because assumptions inherent in the analysis of specific-capacity test data are grossly violated for a well completed in a cavern, data from this well were not included in this analysis and are not listed in table 2. The locations of all other specific-capacity test wells are shown on figure 13. Calculated hydraulic conductivity was greatest for the alluvial deposits (about 31 and $43 \mathrm{ft} / \mathrm{d}$ ) and was least for the Los Puertos (generally less than $7.0 \mathrm{ft} / \mathrm{d}$ ). The calculated hydraulic conductivity of the Aymamón generally ranged from about 1 to $25 \mathrm{ft} / \mathrm{d}$ and averaged $7.5 \mathrm{ft} / \mathrm{d}$. This average value is much less than the average of $150 \mathrm{ft} / \mathrm{d}$ estimated for nine wells in the Río Camuy to Arecibo area (S. Torres-González, U.S. Geological Survey, written commun., 1991) and also is less than the hydraulic conductivity values reported by Giusti $(1978$, p. 25$)$ for other parts of the North Coast Province (143 to $570 \mathrm{ft} / \mathrm{d}$; Giusti, 1978, p. 25). The combined average hydraulic conductivity of the Aymamón Limestone and Los Puertos Formation estimated in this study is about $6.0 \mathrm{ft} / \mathrm{d}$. Transmissivity estimates for the aquifer obtained from the specific-capacity test data range from about 130 to about $3,300 \mathrm{ft}^{2} / \mathrm{d}$ and average about $1,100 \mathrm{ft}^{2} / \mathrm{d}$.
An alternate method of estimating transmissivity is to multiply the average hydraulic-conductivity value for the water-table aquifer $(6.0 \mathrm{ft} / \mathrm{d})$ by the estimated saturated thickness at a particular site. Transmissivity values obtained by this method range from zero to about $4,000 \mathrm{ft}^{2} / \mathrm{d}$, values similar in magnitude to those obtained by the first method.

Because of the relatively low values of hydraulic conductivity in the Aguadilla to Río Camuy area compared to areas to the east, estimated transmissivity values also are much lower than values reported for areas to the east. Transmissivity values in excess of $100,000 \mathrm{ft}^{2} / \mathrm{d}$ have been estimated in other parts of the North Coast Province. Because of the scarcity of specific-capacity data in the study area, estimates of hydraulic conductivity and transmissivity in the study area are poorly distributed spatially and vertically. Hydraulic conductivity based on specific-capacity test data may also be underestimated because an unknown part of the drawdown, used to compute specific capacity, is caused by energy losses in the borehole. Actual hydraulic conductivity and transmissivity could be as large, or nearly as large, as values reported for other parts of the North Coast Province. Ranges of transmissivity were tested during the modeling phase of the

Table 2. Estimated transmissivity and hydraulic conductivity based on specific-capacity test data, northwestern Puerto Rico

[gal/min, gallon per minute; specific capacity in gallon per minute per foot of drawdown [(gal/min)/ft]; $\mathrm{ft}^{2} / \mathrm{d}$, foot squared per day; $\mathrm{ft} / \mathrm{d}$, foot per day; Ls., Limestone; and Fm, Formation]

\begin{tabular}{|c|c|c|c|c|c|c|c|c|c|c|}
\hline Well name & $\begin{array}{c}\text { Symbol } \\
\text { on } \\
\text { figure } \\
13\end{array}$ & $\begin{array}{c}\text { Well } \\
\text { radius } \\
\text { (feet) }\end{array}$ & $\begin{array}{l}\text { Length } \\
\text { of } \\
\text { open } \\
\text { Interval } \\
\text { (feet) }\end{array}$ & $\begin{array}{l}\text { Dis- } \\
\text { charge } \\
\text { (gal } \\
\text { min) }\end{array}$ & $\begin{array}{l}\text { Draw- } \\
\text { down } \\
\text { (foet) }\end{array}$ & $\begin{array}{l}\text { Pump- } \\
\text { Ing } \\
\text { dura- } \\
\text { tion } \\
\text { (hours) }\end{array}$ & $\begin{array}{l}\text { Geologic unit } \\
\text { tested }\end{array}$ & $\begin{array}{c}\text { Specific } \\
\text { capacity } \\
\text { [(gaV } \\
\text { min)/ft] }\end{array}$ & $\begin{array}{c}\text { Trans- } \\
\text { missi- } \\
\text { vity } \\
\left(\mathrm{ft}^{2} / \mathrm{d}\right)\end{array}$ & $\begin{array}{c}\text { Hori- } \\
\text { zontal } \\
\text { hydrau- } \\
\text { lic } \\
\text { conduc- } \\
\text { tivity } \\
\text { (ft/d) }\end{array}$ \\
\hline Campo Alegre \#3 & CA3 & 0.67 & 230 & 300 & 161 & 24 & Aymamón Ls. & 1.9 & 270 & 1.2 \\
\hline Paloma \#1 & PAL1 & .58 & 140 & 150 & 21 & 24 & Aymamón Ls. & 7.1 & 1,300 & 9.3 \\
\hline Zanjas \#2 & ZAN2 & .50 & 365 & 240 & 126 & 48 & Aymamón Ls. & 1.9 & 280 & 0.8 \\
\hline Zanjas \#3 & ZAN3 & .67 & 124 & 250 & 16 & 48 & Aymamón Ls. & 16 & 3,100 & 25 \\
\hline Saltos \#1 & SAL1 & .50 & 60 & 128 & 45 & 48 & Los Puertos Fm. & 2.8 & 430 & 7.1 \\
\hline Saltos \#2 & SAL2 & .42 & 115 & 60 & 39 & 55 & Los Puertos Fm. & 1.5 & 250 & 2.2 \\
\hline Rocha \#2 & ROC2 & .50 & 80 & 115 & 120 & 24 & Los Puertos Fm. & 1.0 & 130 & 1.7 \\
\hline Piedra Gorda \#1 & PG1 & .50 & 140 & 124 & 48 & 48 & Aymamón Ls. & 4.5 & 670 & 4.8 \\
\hline Glamourette & GLAM & .50 & 310 & 120 & 15 & 48 & Aymamón Ls. & 8.0 & 1,600 & 5.2 \\
\hline Campo Alegre \#1 & CAl & .50 & 237 & 300 & 75 & 24 & Los Puertos Fm. & 4.0 & 540 & 2.3 \\
\hline Río Camuy & RCAM & .33 & 42 & 157 & 23 & 24 & Alluvium & 6.8 & 1,300 & 31 \\
\hline Camuy \#2 & CAM2 & .33 & 78 & 223 & 14 & 24 & Alluvium & 15.8 & 3,300 & 43 \\
\hline Pajuil \#2 & PAJ2 & .42 & 193 & 300 & 45 & 24 & Aymamón Ls. & 6.7 & 1,200 & 6.2 \\
\hline
\end{tabular}


study and are discussed further in subsequent sections of this report.

Specific-yield and storage-coefficient values are not available for the study area. Heisel and others (1983, p. 26) used an estimated value of 0.1 for storage coefficient in their electric-analog model of the groundwater system of the North Coast Province; however, that model was not considered to be calibrated for the western part of the North Coast Province. They also stated that a storage-coefficient value of 0.1 "may be high" for a limestone aquifer such as that of the North Coast Province.

\section{Ground-Water Movement}

Ground water in the study area generally moves from the highlands in the south towards the north and west, and, locally, to streams. Figure 14 shows the configuration of the water table and generalized directions of ground-water flow for assumed long-term, averageannual ground-water conditions. Water-level measurements in most of the 34 wells used to construct this map were made during 1984-88, although earlier measurements were used for some wells in order to obtain the most complete areal coverage. Stream altitudes taken from topographic maps were also used in the construction of the water-table map. The general configuration of the water table is similar to that shown for the study area by Giusti (1978, pl. 1) and for November 1984 (A. Torres-González, U.S. Geological Survey, written commun., 1991).

A major ground-water divide extends from the southeastern corner of the study area to the northwest and separates ground-water flow into the study area from flow to the southwest toward the Río Culebrinas (fig. 14). This divide is the southern limit of the study area. Other minor divides occur between the Río Guajataca and the Río Camuy, but otherwise, groundwater flow is essentially toward the coast. The eastern limit of the study area was arbitrarily chosen parallel to the ground-water flow lines, about 5 mi east of the Río Camuy. Localized ground-water flow near the streams and near Lago de Guajataca was not considered in this study, which was regional in scope.

Little information is available concerning vertical ground-water movement. Ground water is assumed to move downward in the southern recharge areas, and to move upward in discharge areas near the coast and offshore. Hydraulic-head data obtained during the drilling of wells NC-6, NC-7, and NC-11 indicate no significant differences in head with depth through the water-table aquifer at those sites (Rodríguez-Martínez and Hartley, 1994). Heads in the artesian zones were 13 to $208 \mathrm{ft}$ higher in the underlying artesian aquifer than the water-table altitude at wells NC-6 and NC-11 at the time that they were drilled (1986-87). The presence of saline water at the base of the water-table aquifer and freshwater in the artesian aquifer (RodríguezMartinez and Hartley, 1994) indicates that the confining unit effectively separates the aquifers and probably prevents upward movement of substantial quantities of water from the artesian aquifer.

\section{Recharge and Discharge}

Because of the high average-annual rainfall (60 to $80 \mathrm{in} / \mathrm{yr}$ ), the general lack of surface-drainage features, and the highly developed karst topography in the highlands, recharge to the ground-water system by infiltration of rainfall should be substantial and rapid. Nearly all recharge to the water-table aquifer of the Aguadilla to Río Camuy area is from infiltration of rainfall, primary into the karst uplands. The absence of vertical head differences throughout the unconfined freshwater sections of wells NC-6 and NC-11 (Rodríguez-Martínez and Hartley, 1994) indicates predominantly horizontal ground-water flow in these areas and a lack of recharge in the north-central part of the study area. A minor amount of recharge also occurs as underflow through the Cibao Formation and Los Puertos Formation in the southeastern part of the study area. Discharge from the ground-water system primarily occurs as leakage to streams and to the sea and, to a lesser degree, as flow to pumping wells.

Two important assumptions were made in order to estimate recharge into the water-table aquifer: (1) The ground-water system is in long-term equilibrium (inflow equals outflow), so that recharge could be calculated as the residual of other water-budget components, and (2) evapotranspiration could be neglected as a ground-water budget component. The second assumption is justified because the amount of rainfall is about twice the amount of evapotranspiration (Giusti, 1978 , p. 32) and because the depth to the water table generally exceeds $10 \mathrm{ft}$ throughout most of the study area. Evapotranspiration generally is insignificant at depths greater than $10 \mathrm{ft}$. Because recharge was calculated as the residual of other budget components, discharge components will be discussed first in this section.

Estimates of ground-water leakage to streams (previously described as "baseflow") may be obtained from the analysis of streamflow data. As stated in the "Surface-Water Hydrology" section, estimated groundwater contribution to the Río Camuy is about $14 \mathrm{ft}^{3} / \mathrm{s}$ between the Bayaney and Hatillo stations, and about $17 \mathrm{ft}^{3} / \mathrm{s}$ to the Río Guajataca between the Guajataca Dam and Quebradillas stations. Applying the rate of 


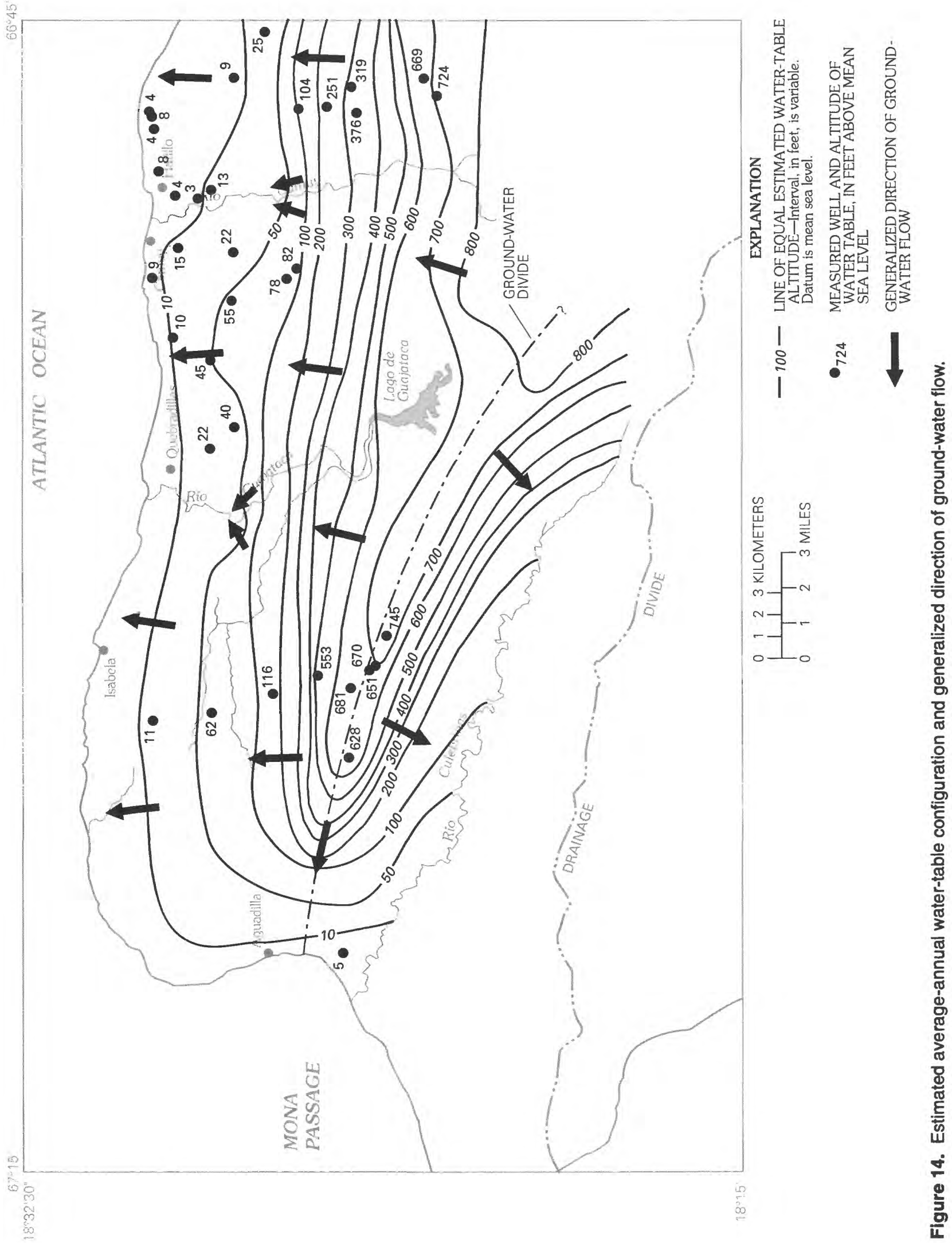


leakage per linear mile for each stream to the ungaged parts of the streams results in an estimated total ground-water leakage to streams of about $43 \mathrm{ft}^{3} / \mathrm{s}$.

Giusti (1978, p. 35) estimated the baseflow components of the Río Camuy and the Río Guajataca to be 44.1 and $17.7 \mathrm{ft}^{3} / \mathrm{s}$, respectively, based on hydrographseparation analysis. This total ground-water leakage to streams of $61.8 \mathrm{ft}^{3} / \mathrm{s}$ is probably somewhat larger than the long-term average because Giusti's baseflow values are based on streamflow data for 1970, a year in which rainfall (and, presumably, streamflow) was about 20 percent greater than average.

Ground-water leakage to the sea occurs as submarine discharge offshore. Three offshore springs have been reported near the extreme northwestern tip of the island (Percious, 1971), and several others along the Atlantic coast are known to local residents. However, the amount of water discharging from these springs has not been measured. Only one terrestrial spring, Ojo de Agua in Aguadilla, is known to discharge near the coast. Discharge from this spring averaged $1.1 \mathrm{ft}^{3} / \mathrm{s}$ from December 1982 through January 1984 (Guzmán-Ríos, 1988, p. 11).

Estimates of ground-water leakage to the sea were made by applying Darcy's Law to six areas of approximately equal hydraulic gradients along the entire coast. The water-table map (fig. 14) was used to calculate average hydraulic gradients near the coast, and the average width of each of the six areas was measured. Area widths ranged from 2.0 to 6.3 miles, and average gradients ranged from about 0.0007 to $0.004 \mathrm{ft} / \mathrm{ft}$. Estimates of transmissivity, ranging from 1,000 to $10,000 \mathrm{ft}^{2} / \mathrm{d}$, based on results of specificcapacity test analyses, and the lower range of values reported by Heisel and others (1983), were used to obtain a range of estimated leakage values to the sea. Using Darcy's Law, the computed ground-water leakage to the sea ranged from about 4 to $36 \mathrm{ft}^{3} / \mathrm{s}$. These estimates include the $1.1 \mathrm{ft} 3 / \mathrm{s}$ average discharge from Ojo de Agua. Heisel and others (1983, p. 33) estimated ground-water discharge to the sea of $82.6 \mathrm{ft}^{3} / \mathrm{s}$ for the Aguadilla to Río Camuy area, based on electric-analog model simulations; however, that model was not considered calibrated for this area (Heisel and others, 1983, p. 36). Their estimate is believed to be too high, because the transmissivity values (about 11,000 to $54,000 \mathrm{ft}^{2} / \mathrm{d}$ ) that they used immediately adjacent to the coast are much greater than any obtained from specificcapacity test data in the study area and are about an order of magnitude larger than those used in the calibrated flow model (discussed in the "Simulation of Ground-Water Flow" section).

Ground-water use in the Aguadilla to Río Camuy area is almost entirely domestic, and most of that water is provided from PRASA public-supply wells. Pumpage from PRASA wells ranged from 2.4 to $7.2 \mathrm{ft}^{3} / \mathrm{s}$ (1.6 to $4.7 \mathrm{Mgal} / \mathrm{d}$ ) between 1985 and 1989 and averaged about $3.0 \mathrm{ft}^{3} / \mathrm{s}$ (S. Guzmán-Ríos, U.S. Geological Survey, written commun., 1991).

The total ground-water discharge from the study area, including pumping and leakage to the sea, is estimated to range from about 50 to $101 \mathrm{ft}^{3} / \mathrm{s}$ (table 3), using the maximum ground-water leakage to streams of $61.8 \mathrm{ft}^{3} / \mathrm{s}$ reported by Giusti $(1978, \mathrm{p} .35)$. If a budget analysis is based on the average leakage rate to streams of $2.6 \mathrm{ft}^{3} / \mathrm{s}$ per linear mile estimated for the Rio Camuy and assumed for the Río Guajataca, then the long-term, average-annual ground-water discharge is estimated to be about $80 \mathrm{ft}^{3} / \mathrm{s}$.

Table 3. Comparison of estimated and model-calculated water-budget components

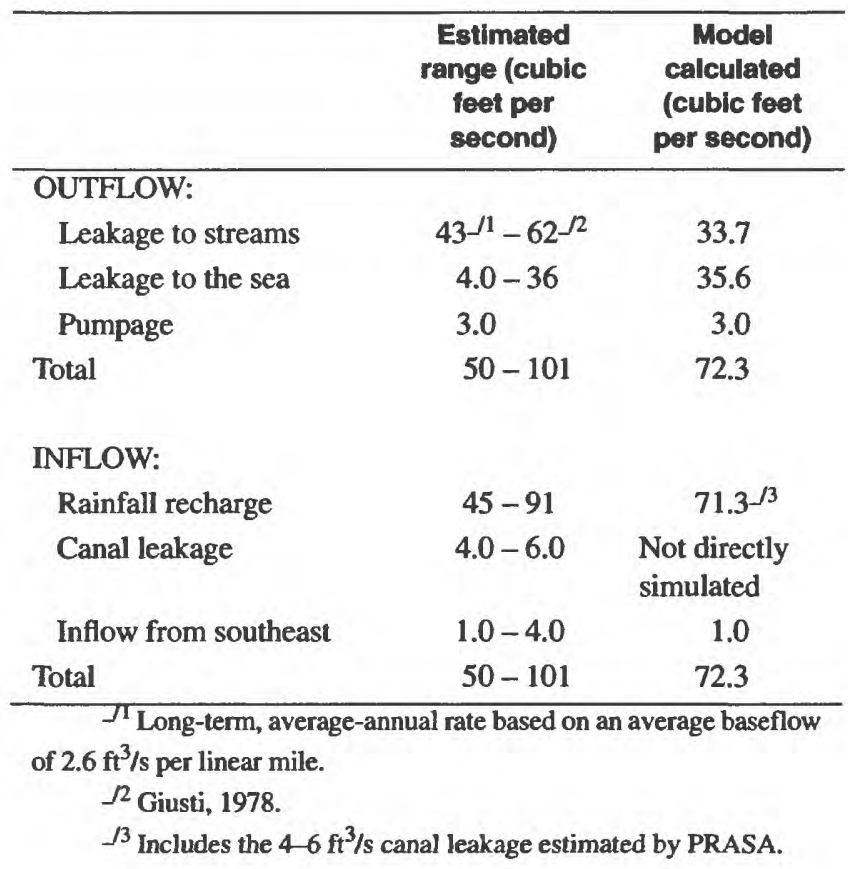

Ground-water inflow at the southeastern boundary of the study area was estimated using Darcy's Law and known or inferred aquifer hydraulic characteristics. The water table in this area is within the Los Puertos Formation and the Cibao Formation, and some ground water flows laterally through these rocks to the water-table aquifer. The hydraulic gradient in this area ranges from 0.02 to $0.03 \mathrm{ft} / \mathrm{ft}$. The average saturated thickness of the rocks is about $\mathbf{4 0} \mathrm{ft}$ (RodríguezMartínez and Hartley, 1994), and the width of the contributing area is about $56,000 \mathrm{ft}$. Estimates of the lateral inflow were made assuming a range of hydraulic-conductivity values for the confining unit of 1.5 to 
$5.7 \mathrm{ft} / \mathrm{d}$ (Giusti, 1978, p. 25). Using these values, the estimated ground-water inflow along the southeastern boundary ranged from about 1 to $4 \mathrm{ft}^{3} / \mathrm{s}$. Ground-water inflow along the eastern boundary is assumed to be zero, because ground-water flow in that area is essentially parallel to the boundary.

Most recharge is believed to occur in the karst highlands to the south, where solution features are most prominent. Heisel and others (1983, p. 21) estimated recharge rates that ranged from 10.2 to $20.9 \mathrm{in} / \mathrm{yr}$ in the study area. Using their analog model, simulated recharge within the outcrop area of the Aymamón Limestone and the Los Puertos Formation was $50.3 \mathrm{ft}^{3} / \mathrm{s}$ (Heisel and others, 1983, p. 32).

Long-term recharge from rainfall was estimated for this study by assuming steady-state ground-water conditions, and calculating recharge as the residual of other water-budget components using the following equation:

$$
R=Q r+Q s+Q p-Q i-Q c
$$

where

$R$ is recharge, in $\mathrm{ft}^{3} / \mathrm{s}$;

$Q r$ is leakage to streams, in $\mathrm{ft}^{3} / \mathrm{s}$;

$Q s$ is leakage to the sea, in $\mathrm{ft}^{3} / \mathrm{s}$;

$Q p$ is pumpage, in $\mathrm{ft}^{3} / \mathrm{s}$;

$Q i$ is inflow from the southeast, in $\mathrm{ft}^{3} / \mathrm{s}$; and

$Q c$ is leakage from diversion canals in $\mathrm{ft}^{3} / \mathrm{s}$.

Estimated rainfall recharge ranged from 45 to $91 \mathrm{ft}^{3} / \mathrm{s}$, using the minimum and maximum values of each budget component from table 3 .

\section{SIMULATION OF GROUND-WATER FLOW}

A numerical model of the ground-water flow system of the Aguadilla to Río Camuy area was used to test concepts of ground-water flow and to assess the need for additional data to facilitate a more complete understanding of the hydrology of the study area. Models are useful tools for this purpose because they integrate all major ground-water flow components, and they allow for the evaluation of the interactions of the various components.

The USGS Modular Ground-Water Flow Model (McDonald and Harbaugh, 1988), commonly referred to as MODFLOW, was used to simulate ground-water flow in the study area. The program uses finitedifference techniques to solve the ground-water flow equation for three-dimensional, steady or non-steady flow, in an isotropic or anisotropic, heterogeneous medium. The Aguadilla to Río Camuy model was constructed and calibrated within the limits of the available data to simulate only steady-state flow conditions. Transient conditions were not simulated, and the model is not intended for use in any transient or predictive ground-water flow problems, which are beyond the scope of this study. A basic assumption of the model is that ground-water flow in the solution-riddled, karstified rocks of the study area can be approximated as flow through a porous medium. Because of the regional scale of the model, such an assumption is justified. Flow through individual solution features or fractures, which might influence ground-water movement locally on a scale of tens to hundreds of feet, is not simulated in this regional-scale model.

\section{Model Construction and Boundary Conditions}

The model of the water-table aquifer represents an area of about $210 \mathrm{mi}^{2}$; however, only about $170 \mathrm{mi}^{2}$ of this area is active (fig. 15). The remaining area either is beneath the ocean or outside of the area that contributes ground-water flow to the study area. The model grid consists of square blocks that are $2,000 \mathrm{ft}$ on each side. A smaller grid-block size was not justified because of the general scarcity of hydrogeologic data. The model grid contains 21 rows and 70 columns of square blocks (fig. 15).

Ground-water flow in the water-table aquifer was initially assumed to be dominantly horizontal. The initial modeling approach, therefore, consisted of one layer, representing a two-dimensional flow system. During the early stages of model calibration, however, a satisfactory match between simulated and measured water levels could not be achieved in the southern part of the model using realistic hydraulic characteristics and recharge rates for that area. Because the southern highlands are believed to be the primary recharge area, significant vertical flow components, not simulated in a two-dimensional model, probably occur in that area. The ground-water flow system, therefore, is best conceptualized as a three-dimensional system in which vertical flow components dominate in the south and horizontal flow components dominate throughout the rest of the study area.

Because of this revised concept of the flow system, a second model layer was added to the model. The upper layer (layer 1) includes only the southern highlands area (model rows 16-21), and represents the upper, saturated parts of the Los Puertos Formation. The lower layer (layer 2) includes all of the active model area and represents the saturated parts of the Aymamón Limestone and the remaining saturated parts of the Los Puertos Formation. The base of the model is the saline-water part of the aquifer in the coastal areas and the top of the confining unit in the rest of the model area. 


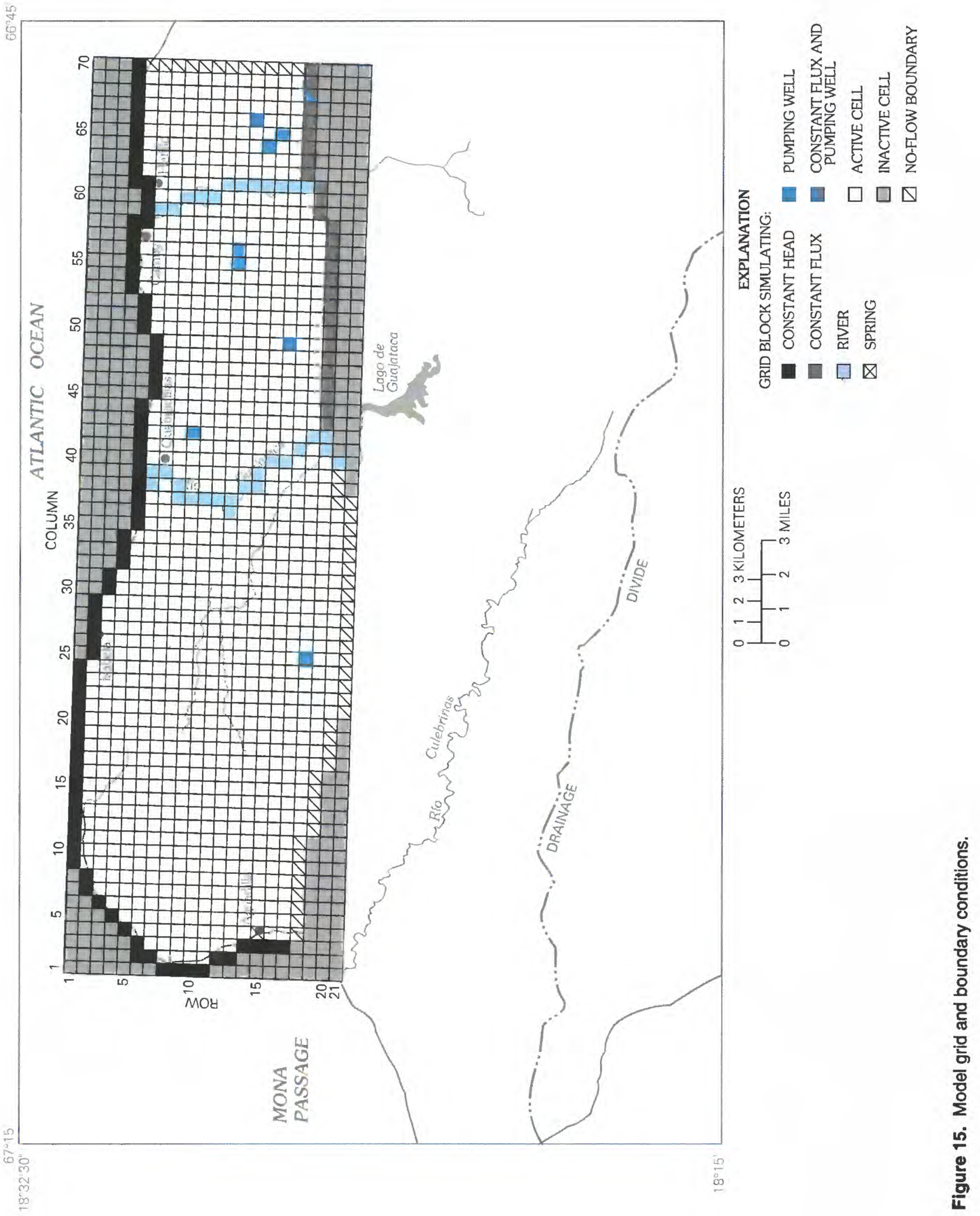


The model boundaries were chosen to approximate natural hydrologic boundaries as closely as possible. The lateral boundaries consist of grid blocks representing constant-head, constant-flux, and no-flow boundaries. Detailed discussions of how the model simulates each of these boundary conditions are beyond the scope of this report but are presented in the MODFLOW documentation (McDonald and Harbaugh, 1988).

The parts of the aquifer underlying the ocean at the coast were represented as a constant-head boundary (fig. 15) in order to simulate ground-water discharge to the sea. The few offshore springs that are documented in this part of the island are reported to be close to the shoreline (Percious, 1971). The aquifer head in the constant-head nodes was set equal to mean sea level throughout the simulation, and the model calculated the amount of ground-water discharge to the sea at each constant-head node.

Constant-flux nodes, represented in the model as constantly recharging wells, were used in the southeastern part of the model in order to simulate groundwater underflow into the study area. An estimated rate of underflow of $0.036 \mathrm{ft}^{3} / \mathrm{s}$ was evenly distributed among each of the 28 grid blocks representing this boundary (fig. 15). The underflow rates were varied throughout the range of estimated rates shown in table 3 as part of the model calibration process.

No-flow boundaries were used along the remaining lateral boundaries on the south and east (fig. 15). These areas represent ground-water divides and areas where ground-water flow is parallel to the model boundary or include outcrop areas of the confining unit or the underlying artesian aquifer.

Internal hydrologic boundaries, such as rivers and pumping wells, also are represented in the model. River nodes (McDonald and Harbaugh, 1988, chap. 6) were used to simulate the interaction between the Rio Camuy, the Río Guajataca, and the water-table aquifer. Values of streambed conductance (McDonald and Harbaugh, 1988, p. 6-4) were calculated for each river node assuming a 1 -ft-thick streambed, an estimated average stream area within the grid block (taken from topographic maps), and an assumed vertical hydraulic conductivity of $1.0 \mathrm{ft} / \mathrm{d}$ for the riverbed. This vertical hydraulic conductivity value is between 0.1 and 0.2 times the average hydraulic conductivity of the aquifer estimated from specific-capacity data, and it was chosen to be a high value because of the common occurrence of solution features within streambeds in the study area. Values of streambed conductance ranged between 20,000 and $270,000 \mathrm{ft}^{2} / \mathrm{d}$, and these values were evaluated during model calibration and sensitivity analysis. The average value of stream stage for each river node was estimated from topographic maps. Stream-bottom altitudes were obtained from stream-gaging records, where available, or assumed to be 1 to $2 \mathrm{ft}$ lower than the average stream stage where data were not available.

Ground-water discharge at Ojo de Agua Spring in Aguadilla was simulated as a drain node (McDonald and Harbaugh, 1988, chap. 9). The drain bottom altitude ( $15 \mathrm{ft}$ ) was estimated from a topographic map, and the conductance value for the drain (McDonald and Harbaugh, 1988, p. 9-5) was arbitrarily chosen at about $1,000 \mathrm{ft}^{2} / \mathrm{d}$. Drain-conductance values were further evaluated during model calibration.

Pumpage from the water-table aquifer for public supply was simulated as constantly discharging wells (McDonald and Harbaugh, 1988, chap. 8). Average pumping rates, calculated from data obtained from PRASA records for 1984-88, were applied to each grid block containing a public-supply well. These rates ranged from about 0.2 to $0.6 \mathrm{ft}^{3} / \mathrm{s}(0.14$ to $0.40 \mathrm{Mgal} / \mathrm{d})$ in the nine pumping-well nodes (fig. 15) and totaled about $3 \mathrm{ft}^{3} / \mathrm{s}(1.9 \mathrm{Mgal} / \mathrm{d})$.

Recharge to the ground-water system by infiltration of rainfall was simulated in the model as a constant inflow rate applied areally over a grid block (McDonald and Harbaugh, 1988, chap. 7). An estimated recharge rate, equivalent to about $10 \mathrm{in} / \mathrm{yr}$, was initially applied uniformly to each active model grid block in the uppermost active layer. This rate and the distribution of discharge were varied significantly during model calibration and are further discussed in the "Steady-State Simulation" section of this report. Leakage from the public-supply diversion canals (4 to $6 \mathrm{ft}^{3} / \mathrm{s}$ ) was not directly simulated in the model because construction details needed for such simulation were not available. This leakage was indirectly simulated through the use of areal recharge in the southern model area, where most of this leakage is believed to occur.

The transmissivity of model layers was calculated by multiplying the average saturated thickness of the aquifer in each grid block in a layer by a uniform hydraulic-conductivity value for that layer. In the southern part of the model, each layer was assigned one-half of the total saturated thickness of the aquifer. The initial values of hydraulic conductivity used were $6.0 \mathrm{ft} / \mathrm{d}$ for layer 2 and $2.0 \mathrm{ft} / \mathrm{d}$ for layer 1 , based on specific-capacity test data. These values were varied and evaluated during model calibration and sensitivity analysis.

The aquifer is assumed to be isotropic, in that horizontal hydraulic-conductivity values are equal in all directions. This assumption was tested during model sensitivity analysis and is discussed further in that section of the report. 
For multiple layers, MODFLOW requires the use of a vertical leakance value to provide hydraulic connection between layers. Vertical leakance for two adjacent model layers, such as those in this model, may be calculated by the equation:

$$
V_{l}=\frac{1}{\frac{\left(b_{1} / 2\right)}{\left(K_{z}^{1}\right)}+\frac{\left(b_{2} / 2\right)}{\left(K_{z}^{2}\right)}}
$$

where

$V_{l}$ is vertical leakance, in ( $\left.\mathrm{ft} / \mathrm{d}\right) / \mathrm{ft}$;

$b_{1}$ is thickness of the upper model layer, in $\mathrm{ft}$;

$b_{2}$ is thickness of the lower model layer, in $\mathrm{ft}$;

$K_{z}{ }^{1}$ is the vertical hydraulic conductivity of the upper layer, in $\mathrm{ft} / \mathrm{d}$; and

$K_{z}^{2}$ is the vertical hydraulic conductivity of the lower layer, in ft/d (McDonald and Harbaugh, 1988, p. 5-13).

Because both the saturated thickness and the vertical hydraulic conductivity of the aquifer are essentially unknown in the southern part of the model area, calculation of vertical leakance for each grid block was not justified. Consequently, a uniform value for vertical leakance was used. The initial value chosen was $0.006(\mathrm{ft} / \mathrm{d}) / \mathrm{ft}$, which corresponded to assumed values of $b_{1}=b_{2}=50 \mathrm{ft}, K_{z}{ }^{1}=0.2 \mathrm{ft} / \mathrm{d}$, and $K_{z}^{2}=0.7 \mathrm{ft} / \mathrm{d}$. The vertical hydraulic-conductivity values are assumed to be equal to one-tenth of the initial horizontal hydraulicconductivity values for each layer. Such an assumption is common in simulation of layered sedimentary-rock aquifers and is reasonable to use for initial simulations. The value of vertical leakance was varied and evaluated during model calibration and sensitivity analysis.

\section{Steady-State Simulation}

Steady-state conditions were assumed for the simulation of ground-water flow in the Aguadilla to Río Camuy area. This assumption is justified because the aquifer is only minimally used as a water-supply source in the study area, and storage changes caused by pumping are minimal. In addition, precipitation (and, presumably, recharge) during the mid- to late-1980's was close to the long-term average. For these reasons, no significant addition to or depletion from groundwater storage is believed to have occurred during the study period, although long-term water-level data in the study area are not available to support this belief. Simulated water levels and water-budget components are, therefore, considered long-term, average values for the water-table aquifer.

Simulated water levels were compared to measured water levels in 20 wells ( 3 in layer 1, 17 in layer 2). In order to evaluate model results, the root mean square error (RMSE) was calculated according to the equation:

$$
R M S E=\sqrt{\frac{\sum_{i=1}^{N}\left(h_{i}^{m}-h_{i}^{c}\right)^{2}}{N}}
$$

where

$N$ is the number of observations;

$h_{i}^{m}$ is the estimated water level, in $\mathrm{ft}$; and

$h_{i}^{c}$ is the simulated water level, in $\mathrm{ft}$.

The smaller the RMSE value, the closer the overall match is between simulated and measured water levels. The final calibrated values of RMSE were $87.7 \mathrm{ft}$ for layer $1,17.6 \mathrm{ft}$ for layer 2 , and $37.7 \mathrm{ft}$ for both layers. The RMSE value was strongly influenced by the large difference $(-149 \mathrm{ft})$ between simulated and measured water levels at the Monte Encantado well (fig. 16). The negative sign indicates that simulated water levels were lower than measured levels. The Monte Encantado well is completed in a cavern in the southern highlands, and the measured water level in the well may only represent a very local hydrologic condition, such as perched water on the cavern floor. If the water level in this well is not included in the RMSE calculation, the RMSE values are $19.5 \mathrm{ft}$ for layer $1,17.6 \mathrm{ft}$ for layer 2 , and $17.9 \mathrm{ft}$ for both layers. Simulated water levels average about $4 \mathrm{ft}$ higher than measured water levels. The absolute difference between simulated and average measured water levels, not including the Monte Encantado well, ranged from 1.5 to $39.2 \mathrm{ft}$, and the overall shape of the simulated water table (fig. 16) is similar to the estimated average water-table configuration (fig. 14).

Model-calculated water-budget components were within the range of estimated components (table 3). Overall, the model-calculated budget is at the high end of the estimated range. Model-calculated leakage to streams is about 20 percent less than the estimated leakage based on a baseflow of $2.6 \mathrm{ft}^{3} / \mathrm{s}$ per linear mile. This difference may indicate that (1) leakage to streams was overestimated, (2) the streambedconductance value was underestimated (that is, the simulated connection between the aquifer and the stream was too small), or (3) simulated recharge was too small. Simulated recharge $\left(71.3 \mathrm{ft}^{3} / \mathrm{s}\right)$ was about 10 percent less than the estimated maximum rate of 


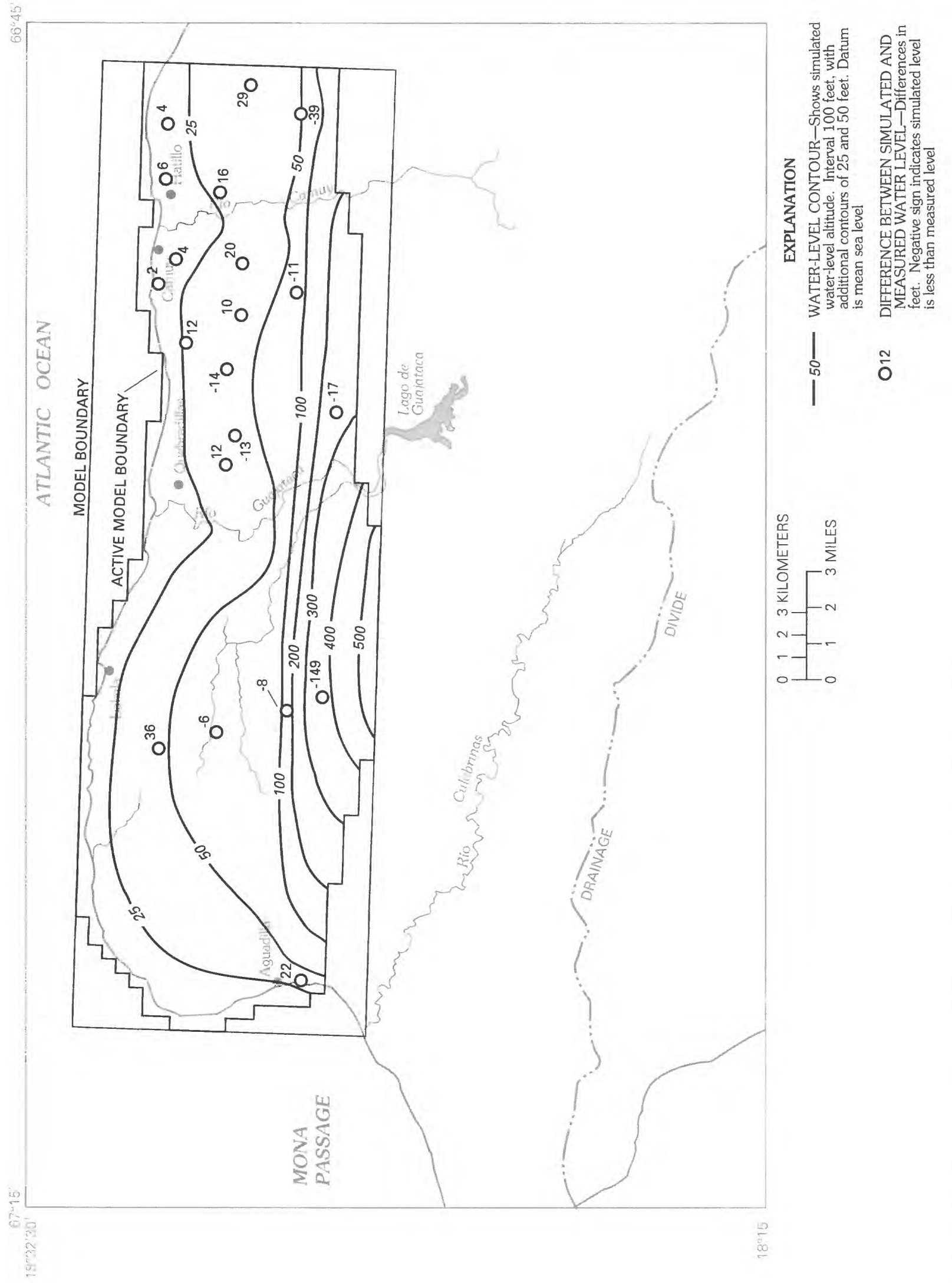

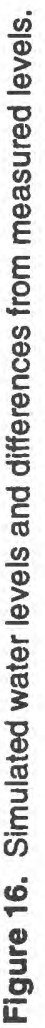


$78 \mathrm{ft}^{3} / \mathrm{s}$, based on baseflow data $\left(43 \mathrm{ft}^{3} / \mathrm{s}\right)$, the maximum rate of outflow to the sea $\left(31 \mathrm{ft}^{3} / \mathrm{s}\right)$, pumpage $\left(3.0 \mathrm{ft}^{3} / \mathrm{s}\right)$, and inflow from the southeast of $1.0 \mathrm{ft}^{3} / \mathrm{s}$. However, simulation of larger recharge rates would have increased simulated water levels, which were already higher than measured levels.

During the early stages of model calibration, simulated water levels generally were too high in the northern part of the model and too low in the southern part. The steep hydraulic gradient between the northern and southern areas was not adequately simulated. In order to better simulate this steep gradient, higher transmissivity and lower recharge were required in the north and lower transmissivity and higher recharge were required in the south. Changes to one or the other of these parameters alone did not increase the gradient sufficiently.

Transmissivity values were increased, overall, from initial estimates. The hydraulic conductivity for layer 1 was increased to $11 \mathrm{ft} / \mathrm{d}$ from $2.0 \mathrm{ft} / \mathrm{d}$. Although this is a substantial increase over original transmissivity estimates for layer 1 , the resulting transmissivity of layer 1 is still almost an order of magnitude lower than that of layer 2 immediately to the north. Use of lower hydraulic-conductivity values resulted in a better match between measured and simulated water levels for the Monte Encantado well, but the match for the other two wells in layer 1 was worse. Average hydraulic conductivity for layer 2 was increased to $67 \mathrm{ft} / \mathrm{d}$ from $6.0 \mathrm{ft} / \mathrm{d}$. This value is about an order of magnitude higher than that estimated from specific-capacity data in the area; however, that data set is small and may not be representative. The adjusted values of hydraulic conductivity and resulting transmissivities are similar to those determined for similar hydrogeologic units to the east (S. Torres-González, written commun., 1992). The final calibrated distributions of transmissivity values used in the model are shown in figures $\mathbf{1 7}$ and 18 .

Many simulations were made with various rates and distributions of recharge from precipitation. Simulations in which a range of recharge rates were distributed uniformly over the entire model area, produced poor matches between simulated and measured water levels, particularly in the northern two-thirds of the model. Simulations in which recharge was distributed only over layer 1 , in the southern model area, produced much closer matches. This result supports the concept that nearly all of the recharge to the ground-water system occurs in the southern highlands. The area over which recharge was distributed is shown in figure 19 . A uniform rate of about $22 \mathrm{in} / \mathrm{yr}$ was applied to this area. This relatively high rate (about 30 percent of average annual rainfall) is not unreasonable for a karst area in which little runoff occurs and is similar to rates used in other flow models in hydrogeologically similar areas to the east (Torres-González, 1985, p. 25;

Gómez-Gómez and Torres-Sierra, 1988). The recharge rate used in the model is slightly greater than the maximum rate used by Heisel and others (1983, p. 32) of $20.9 \mathrm{in} / \mathrm{yr}$.

Reducing the vertical-leakance value from 0.006 to $0.0001(\mathrm{ft} / \mathrm{d}) / \mathrm{ft}$ resulted in a better match between simulated and measured water levels in layer 1 but did not significantly change simulated water levels in layer 2. Because of the improved match in water levels for layer 1 , this reduced leakance value was used as the calibrated value. A reduced leakance value implies that the vertical hydraulic conductivity of the aquifer may be about an order of magnitude lower than initially assumed for model construction.

Constant flux rates in the southeastern part of the model were varied during calibration. A rate of about $1 \mathrm{ft} / \mathrm{s}$, divided equally among the constant-flux nodes, produced an acceptable match between simulated and measured water levels. This rate was further evaluated during sensitivity analysis.

The values chosen for river and drain conductance, discussed in the previous section, resulted in an acceptable match between simulated and measured water levels. Model-calculated rates of leakage to streams and discharge at Ojo de Agua were within the estimated ranges using these values and were considered acceptable.

The results of the steady-state simulation are considered acceptable, considering the general lack of hydrogeologic data and the uncertainties in the estimates of water-budget components. Model results were non-unique, however, because combinations of input data other than those documented here produced reasonable matches between simulated and measured water levels and calculated budget components that were within the wide range of estimated budget components. Because of the lack of hydrogeologic data in the study area and the large degree of uncertainty in the estimated water-budget components, the model should be considered only partially, or incompletely, calibrated. The present model is the best that can be produced within the limits of available data, and the input data documented here produced a combination of acceptable matches between simulated and measured water levels and water-budget components that are reasonable. Limitations of the simulation results and conclusions, and additional data needs are discussed in the following sections. 


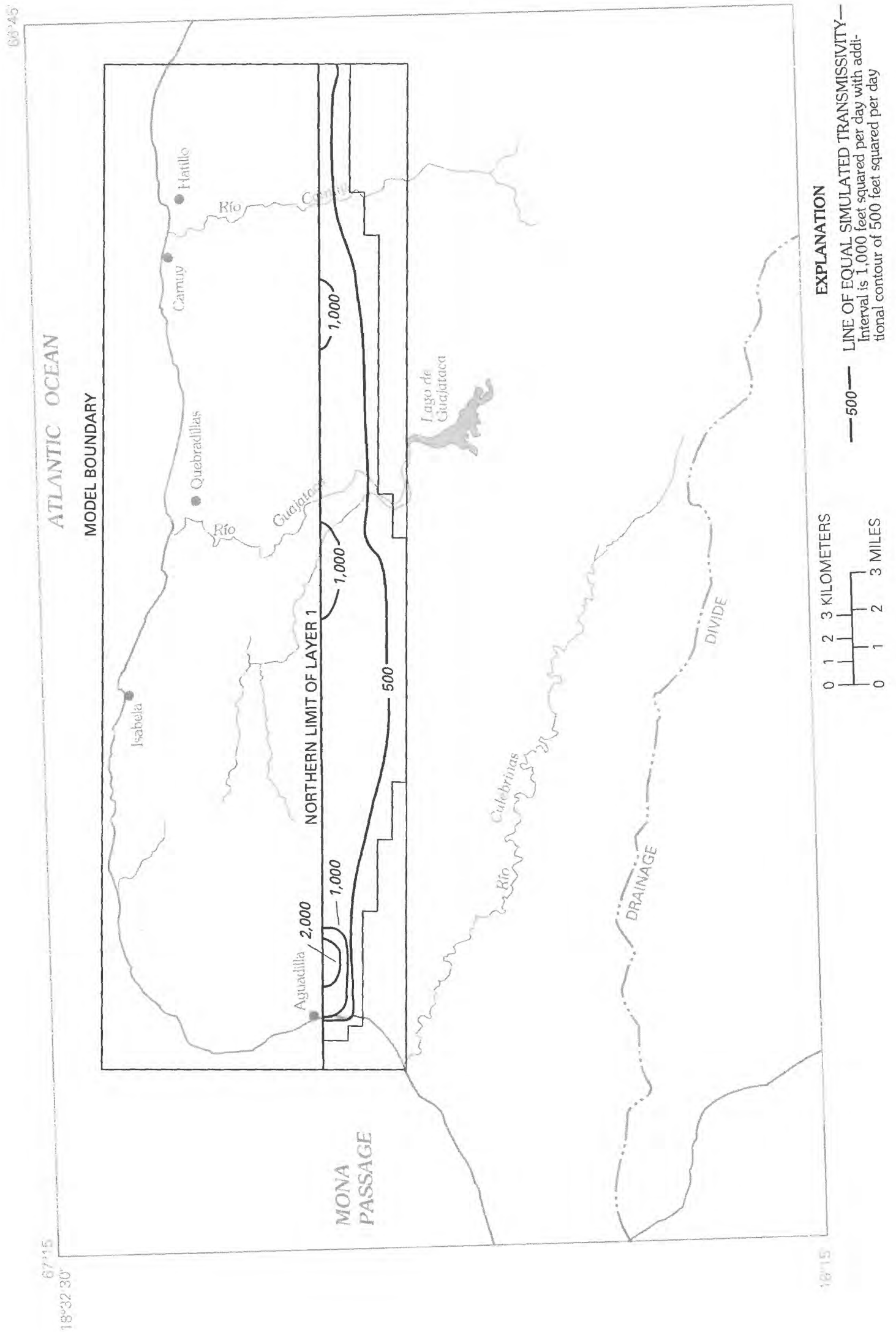

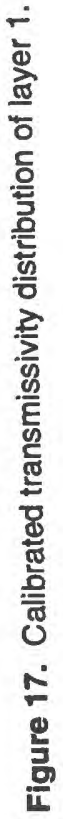




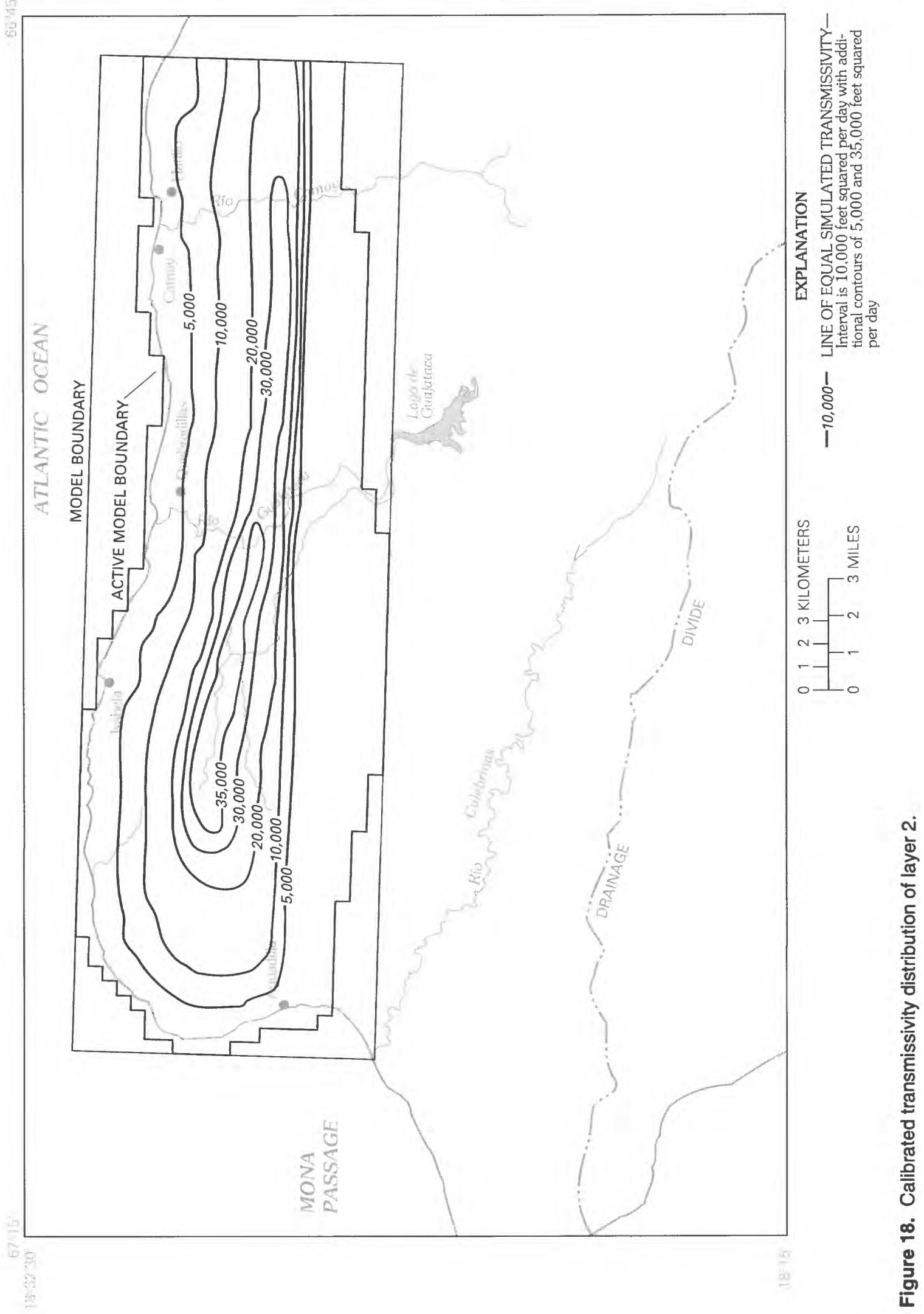




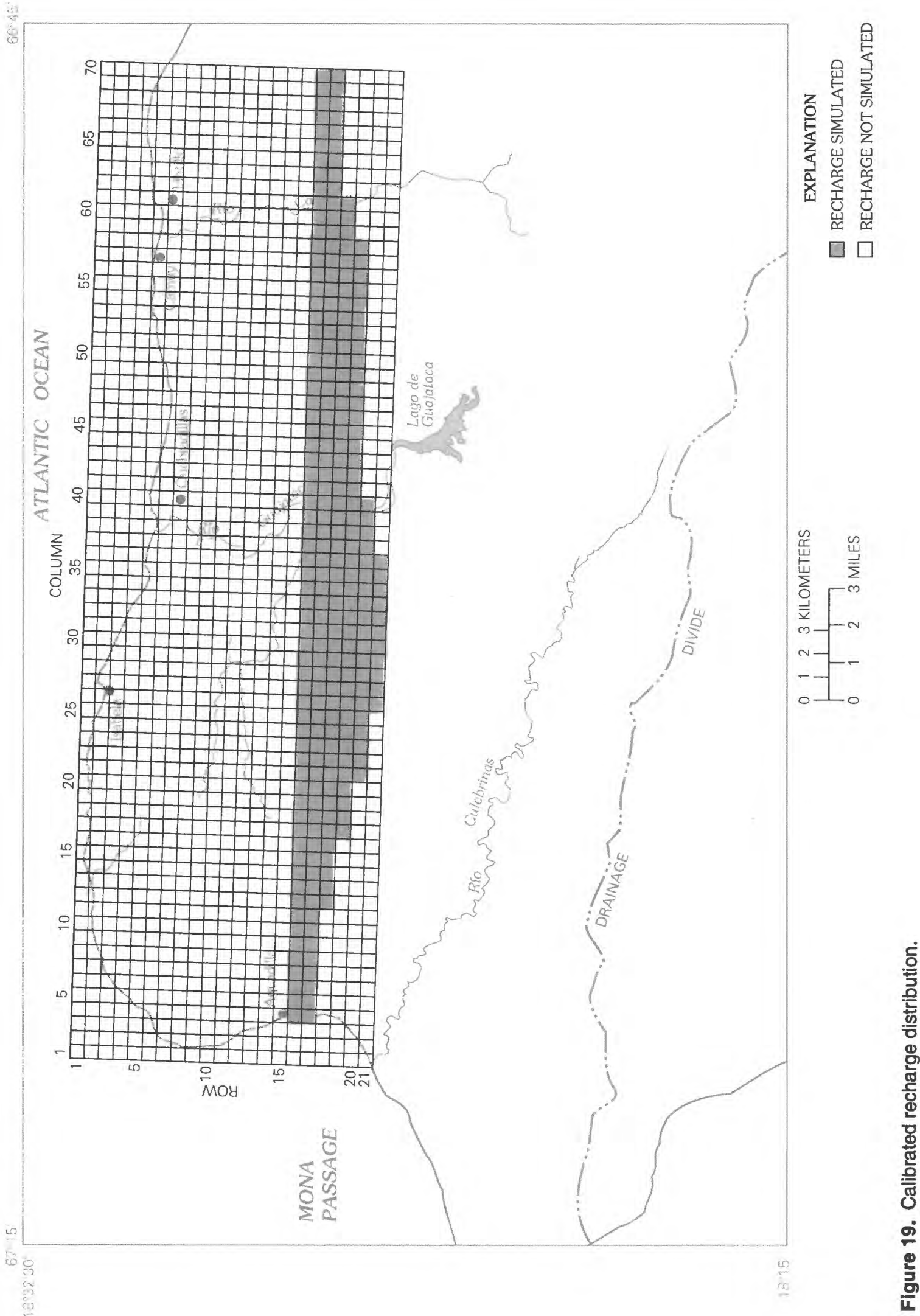




\section{Sensitivity Analysis}

The sensitivity of the model to changes in various model-input parameters was evaluated by a sensitivity analysis. The relative sensitivity of the model to these changes indicates the degree of importance of individual parameters to the simulation of groundwater flow, thus providing an indication of the uniqueness of the model calibration. For example, if similar simulation results are obtained when a model-input parameter is varied over a large range of values from the calibrated value, then the model is considered to be insensitive to that parameter and the model solution is considered non-unique. Additionally, if the model is insensitive to a parameter, then obtaining additional field information to refine knowledge of that parameter would do little to improve simulation results.

The parameters tested in the sensitivity analysis were recharge, hydraulic-conductivity of layers 1 and 2 , row-to-column anisotropy of hydraulic conductivity, river conductance and vertical leakance values, and constant-flux rate across the southeastern model boundary. Each parameter was adjusted uniformly over the entire model area, where applicable, and the RMSE was calculated and compared to the calibrated RMSE value for layer 2 of $17.6 \mathrm{ft}$. Each parameter was evaluated independently, in that all other parameters were held constant while the tested parameter was varied.

Model sensitivity was evaluated by comparison of RMSE values only for layer 2 . The calculated RMSE for layer 1 was not used in the sensitivity analysis because the RMSE for layer 1 was dominated by the large difference in simulated and measured water levels for the Monte Encantado well (in layer 1). Any model simulation that reduced this difference greatly reduced the calculated RMSE value for layer 1 and for both layers. Eliminating the Monte Encantado well from the RMSE calculation resulted in a RMSE for layer 1 calculated from only two data points, and the RMSE value of such a small data set was considered to be unreliable. Use of the RMSE for layer 2 alone was deemed sufficient to evaluate model sensitivity because nearly all of the data used in the RMSE calculation are for layer 2 .

The model was most sensitive to changes in transmissivity of layer 2, recharge, and anisotropy but was relatively insensitive to changes in river conductance and vertical leakance. Model results for layer 1 are probably sensitive to transmissivity of layer 1; however, this assumption could not be evaluated with the small data set available for RMSE calculations in layer 1. Model results for layer 2 were insensitive to changes in the transmissivity of layer 1.

The model was more sensitive to decreases in the transmissivity of layer 2 than to increases in transmissivity (fig. 20). Reducing the transmissivity of layer 2 to one-quarter of the calibrated value resulted in a RMSE of $78.4 \mathrm{ft}$, but increasing the hydraulic conductivity by 3 times the calibrated value resulted in a RMSE of $29.5 \mathrm{ft}$.

The model was more sensitive to increases in recharge rate than to decreases in recharge (fig. 20). Increasing the recharge rate to 3 times the calibrated value resulted in a RMSE of $65.7 \mathrm{ft}$, but decreasing the rate to one-quarter of the calibrated value resulted in a RMSE of $30.9 \mathrm{ft}$.

Simulation of the aquifer as an anisotropic system, in which hydraulic conductivity was greater in either an east-west or north-south direction, resulted in RMSE values that were higher than the calibrated value. This result tends to confirm the assumption that the aquifer is isotropic on a regional scale. Simulation of the aquifer with a hydraulic conductivity that was 4 times greater in an east-west direction than a northsouth direction resulted in a RMSE of $39.0 \mathrm{ft}$. Simulation of the aquifer with a hydraulic conductivity that was 4 times greater in north-south direction than an east-west direction resulted in a RMSE of $32.0 \mathrm{ft}$.

The model was least sensitive to changes in river conductance, vertical leakance, and constant-flux rate. These values could be changed by an order of magnitude or more without significantly increasing the RMSE over the calibrated RMSE value (17.6 ft). The model was about equally sensitive to increases and decreases in river conductance, but it was more sensitive to decreases in vertical leakance than to increases (fig. 21). The model sensitivity to vertical leakance cannot be fully evaluated by only considering the RMSE of layer 2 because changing the vertical leakance can change the simulated water levels in layer 1. However, data are insufficient to reliably calculate the RMSE of layer 1.

The model was also insensitive to the constant flux rate across the southeastern boundary. Increasing or decreasing the rate by an order of magnitude resulted in changes in RMSE values of less than $0.2 \mathrm{ft}$ from the calibrated RMSE value. The insensitivity of the model to this parameter is because underflow in this area is a small percentage of the total water budget of the study area. 


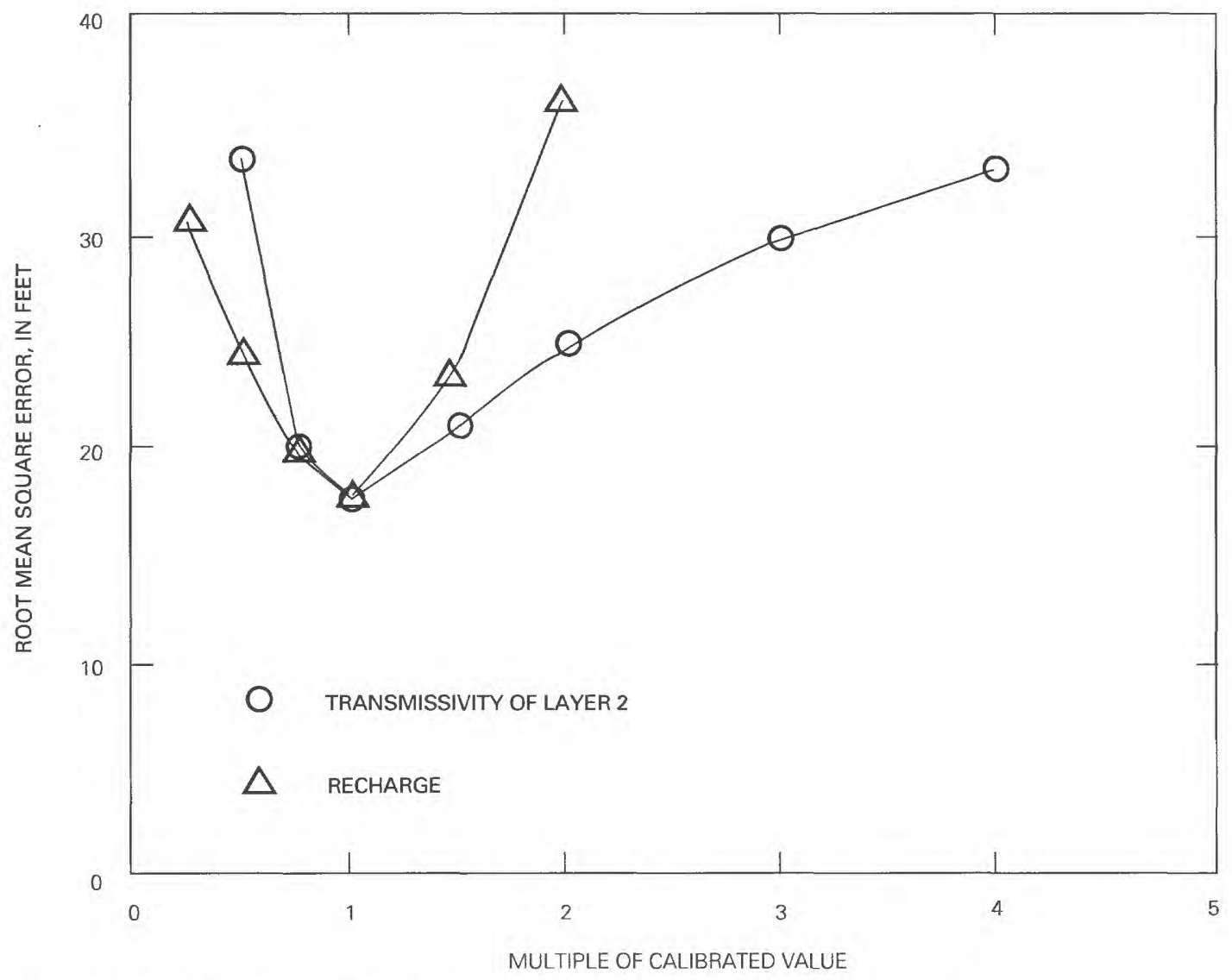

Figure 20. Model sensitivity to changes in recharge and transmissivity of layer 2. 


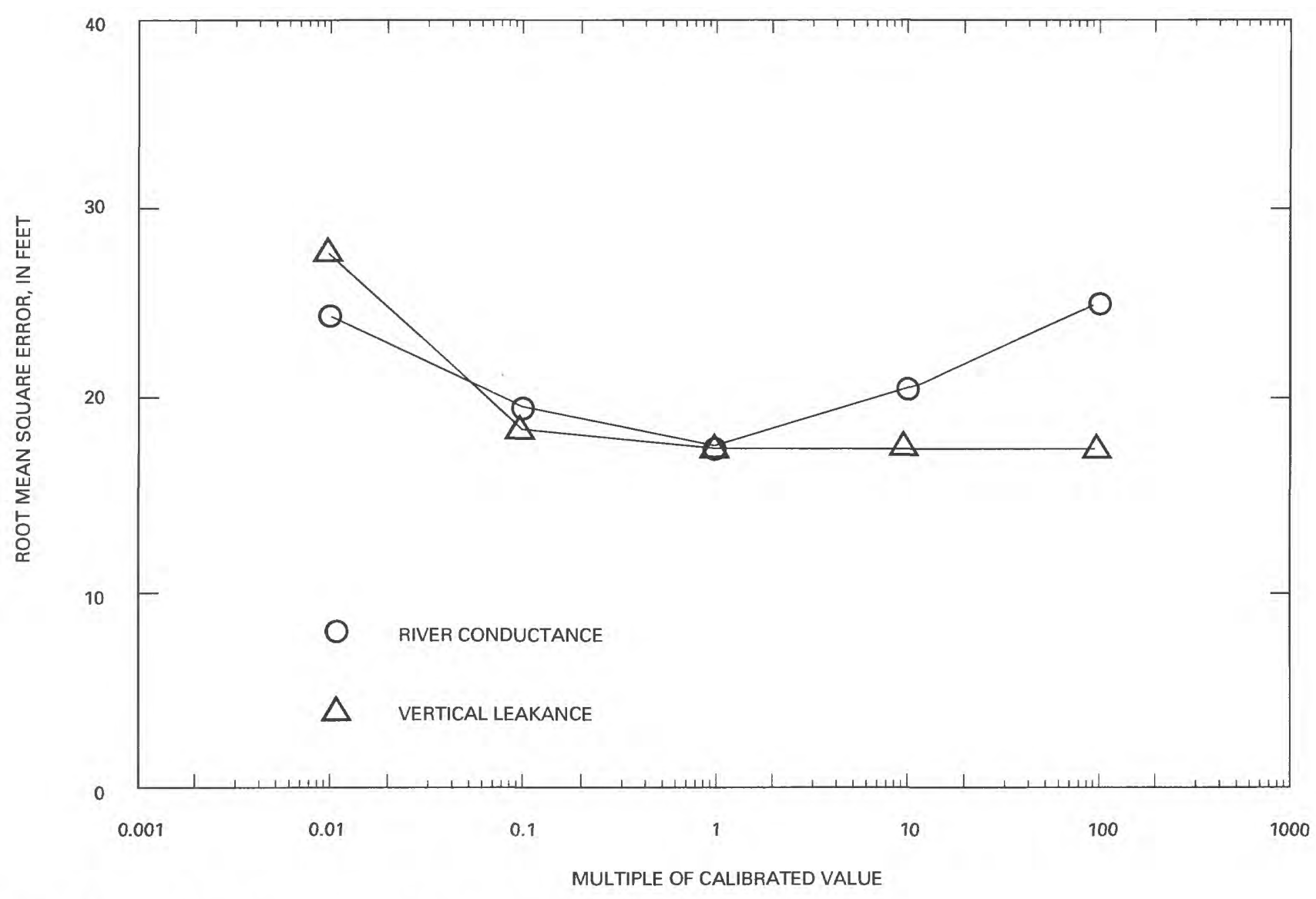

Figure 21. Model sensitivity to changes in river conductance and vertical leakance. 


\section{Model Limitations and Additional Data Needs}

Models, by their very nature, are not exact replicas of natural systems. They are limited by such factors as scale, inaccuracies in estimated hydraulic characteristics and in representing boundary conditions, and by the underlying assumptions used in their construction. The model constructed for this study is no exception. For example, the grid block size $(2,000 \mathrm{ft}$ per side $)$ is too large to accurately simulate ground-water flow through individual fractures or solution openings. The model is based on the assumption that flow through fractures and solution openings, common in limestone aquifers, can be approximated as flow through an isotropic, porous media. Inaccuracies in the simulation results could be caused by deviations of existing hydrologic conditions from this assumption. This is probably the case for the poor match between simulated and measured water levels for the Monte Encantado well. The assumption of porousmedia equivalence is generally valid for regional-scale models such as the present model. The focus of this section is on limitations of the model and specific additional data needed to minimize these limitations.

The model is most limited by the lack of sufficient hydrogeologic data to adequately evaluate simulation results. Because of the limited available data, the model can only be considered partially calibrated. Additional water-level data, distributed throughout the study area, are needed to better define the flow system and for comparison to simulated water levels. Additional information is needed on hydraulic conductivity, aquifer saturated thickness, the position of the salinewater/freshwater interface, and the locations and discharge of onshore and offshore springs. Continued monitoring of streamflow for the Río Camuy and the Río Guajatatca will provide more accurate information on ground-water discharge to streams, which may allow more accurate estimates of other ground-water budget components to be made.

An important assumption for the model was that the flow system is at steady state and that the water levels used for comparison to simulated water levels are representative of average, steady-state conditions. Because of the relatively unstressed state of the system, this assumption probably is valid; however, discrepancies between simulated and measured water levels may be due in part to localized deviations from this assumption. Continuous, long-term water-level data are needed across the study area to better define averageannual ground-water conditions and to monitor future deviations from those conditions as the system is developed. Accurate data on ground-water use also are required to address these issues.
Model boundaries probably are adequately simulated because they were chosen to closely approximate natural hydrologic boundaries. Changing the position of the constant-head or no-flow boundaries to account for any inaccuracies in their simulated positions would probably have minimal impact on simulation results; however, this hypothesis was not tested. Model results were insensitive to variation of the constant-flux rate across the southeastern boundary, so that any inaccuracies in the simulation of that boundary probably would not significantly affect simulation results.

Despite the limitations discussed in this section, the model provides valuable insights to the water-table aquifer of the Aguadilla to Río Camuy area. The initial concept of the system, that of a single aquifer dominated by horizontal flow components, was found to be inadequate to simulate ground-water flow in the southern part of the study area. The southern part of the study area is dominated by vertical flow components that provide recharge to the rest of the aquifer. In order to adequately simulate the flow system, the model required hydraulic conductivity values that were about an order of magnitude greater than initial estimates. The aquifer may be able to provide a significant amount of water for public supply, and additional ground-water development may be possible. In order to further evaluate the potential for additional development, more accurate information is needed on averageannual ground-water conditions, as well as information on the storage properties of the aquifer. No attempt was made to evaluate the storage properties of the aquifer by means of transient model calibrations; consequently, use of the present model for analysis of transient ground-water problems would be inappropriate.

\section{SUMMARY}

A long-term hydrologic investigation was undertaken by the USGS in 1984 to provide a comprehensive appraisal of the ground-water resources of the North Coast Province of Puerto Rico. The aquifers of the Aguadilla to Río Camuy area, covering about $200 \mathrm{mi}^{2}$ in the northwestern part of the island, are the least developed of those on the north coast, and relatively little information is available on the ground-water system of the area. The present study defines the hydrology of the Aguadilla to Río Camuy area to the extent possible, within the constraints of available data. The information compiled for the study was used to construct a numerical ground-water-flow model to test concepts of ground-water flow and to assess additional data needed 
for a more complete understanding of the hydrologic system.

The study area consists of an uplifted rolling plain to the north that lies 200 to $400 \mathrm{ft}$ above sea level, and a heavily forested karst upland to the south. Few surface-drainage features are present in the study area. The only major streams are the Río Camuy and the Río Guajataca. Most water supply in the area is obtained from Lago de Guajataca, just south of the study area, and ground-water use is minimal.

Sedimentary rocks of Tertiary age comprise the bedrock of the Aguadilla to Río Camuy area. These rocks, mainly composed of limestone and calcareous clay, include (in ascending order) the San Sebastián Formation, Lares Limestone, Cibao Formation, Los Puertos Formation, Aymamón Limestone, and Quebradillas Limestone. The Tertiary rocks locally are overlain by Quaternary alluvium and other surficial deposits. The rocks dip from 4 to 7 degrees to the north, and the total sedimentary rock sequence may be as much as $6,000 \mathrm{ft}$ thick near the Atlantic coast.

The Río Camuy, in the eastern part of the study area, is unregulated. The river had a mean-annual flow between 1985 and 1990 of $110 \mathrm{ft}^{3} / \mathrm{s}$ upstream near Bayaney, and $177 \mathrm{ft}^{3} / \mathrm{s}$ at Hatillo near the coast. Baseflows for the Río Camuy are $57.5 \mathrm{ft}^{3} / \mathrm{s}$ near Bayaney and $72.5 \mathrm{ft}^{3} / \mathrm{s}$ near Hatillo. The ground-water discharge to the Río Camuy between these gaging stations is estimated to be about $15.0 \mathrm{ft}^{3} / \mathrm{s}$, or $2.6 \mathrm{ft}^{3} / \mathrm{s}$ per linear mile, on the basis of the difference in baseflows at the two gaging stations.

The flow of the Rio Guajataca is regulated by Guajataca Dam at Lago de Guajataca. Mean-annual flow between 1984 and 1989 below Guajataca Dam was $33.6 \mathrm{ft}^{3} / \mathrm{s}$, and $91.5 \mathrm{ft}^{3} / \mathrm{s}$ at Quebradillas near the coast. Ground-water discharge to the Rio Guajataca between these stations is estimated to be about $17.2 \mathrm{ft}^{3} / \mathrm{s}$, assuming that the average ground-water leakage obtained for the Río Camuy can also be applied to the Río Guajataca. The median diversion from Lago de Guajataca for water supply between 1985-90 was about $14 \mathrm{ft}^{3} / \mathrm{s}$; however, from 4 to $6 \mathrm{ft}^{3} / \mathrm{s}$ may have been lost because of seepage from the diversion canal.

Both water-table and artesian aquifers are present in the Aguadilla to Río Camuy area; however, most ground water occurs within the water-table aquifer, which was the primary focus of the study. The water-table aquifer extends from the water table to the top of the freshwater/saline-water interface near the coast, and to the top of the first underlying confining unit in the rest of the study area. The top of the confining unit generally is within the unnamed upper member of the Cibao Formation; however, it is within the
Los Puertos Formation in the eastern part of the study area.

The aquifer is primarily composed of rocks of the Aymamón Limestone and the Los Puertos Formation. The Aymamón is the most important part of the aquifer in the north, because the Los Puertos lies below the freshwater/saline-water interface in that area. In the south, the Los Puertos is the major part of the aquifer because the Aymamón lies above the water table in that area. The estimated saturated thickness of the water-table aquifer ranges from zero at the southern limit of the aquifer to more than $600 \mathrm{ft}$ south of Isabela in the northwestern part of the study area.

Hydraulic conductivity of the Aymamón Limestone, based on specific-capacity test data for seven wells, ranges from 1 to $25 \mathrm{ft} / \mathrm{d}$ and averages $7.5 \mathrm{ft} / \mathrm{d}$. Hydraulic conductivity of the Los Puertos Formation, based on specific-capacity test data for four wells, was generally less than $7.0 \mathrm{ft} / \mathrm{d}$. The average hydraulicconductivity value for the Aymamón Limestone and the Los Puertos Formation is about $6.0 \mathrm{ft} / \mathrm{d}$. These hydraulic-conductivity values are less than average values for the water-table aquifer reported for an adjacent area to the east ( $150 \mathrm{ft} / \mathrm{d})$ and for other parts of the North Coast Province (143 to $570 \mathrm{ft} / \mathrm{d}$ ). Because of the small number of available specific-capacity test data in the study area, the hydraulic-conductivity values estimated here may not be representative of the entire study area. Transmissivity values, based on the average hydraulic-conductivity value for the aquifer and the estimated range of saturated thickness, range from zero to about $4,000 \mathrm{ft}^{2} / \mathrm{d}$. Transmissivity values to the east of the study area, however, are in excess of $100,000 \mathrm{ft}^{2} / \mathrm{d}$.

Ground water generally moves from the highlands in the south towards the sea to the north and west, and, locally, to streams. A major ground-water divide extends from the southeastern corner of the study area to the northwest, and separates flow into the study area from flow to the southwest towards the Río Culebrinas.

Nearly all recharge to the aquifer is from infiltration of rainfall into the karst uplands. Discharge from the aquifer primarily occurs as leakage to streams and to the sea, and to a lesser degree as flow to wells. Estimates of recharge range from 45 to $91 \mathrm{ft}^{3} / \mathrm{s}$; however, the upper estimate is thought to be excessive. Groundwater flow from the southeast into the study area is estimated to range from 1.0 to $4.0 \mathrm{ft}^{3} / \mathrm{s}$. Ground-water discharge to streams is estimated to range from 43 to $62 \mathrm{ft}^{3} / \mathrm{s}$, although the upper estimate is thought to be excessive. Discharge to the sea is estimated to range from 4.0 to $36 \mathrm{ft}^{3} / \mathrm{s}$, and average pumpage between 1985 and 1989 was about $3.0 \mathrm{ft}^{3 /} / \mathrm{s}$. 
A two-layer, three-dimensional, steady-state, numerical model was constructed to simulate groundwater flow. Two layers were required in the southern part of the study area in order to adequately simulate vertical-flow components in the recharge area. A basic assumption of the model is that ground-water flow in the karst rocks of the study area can be approximated as flow through an isotropic, porous media. Recharge, at a rate of $22 \mathrm{in} / \mathrm{yr}$, was simulated only over the southern highlands area.

Simulated water levels generally matched average measured water levels, except at one well completed in a cavern that may reflect very localized flow conditions. Calculated values of root mean square error, disregarding the anomalous well, were $19.5 \mathrm{ft}$ for layer 1 and $17.6 \mathrm{ft}$ for layer 2 . The model-calculated water budget was toward the high end of the estimated water-budget range. Simulated transmissivity values were higher than estimated values for the study area; however, the simulated transmissivity values are similar to those estimated for adjacent areas to the east.

The results of the steady-state simulation are considered to be acceptable, given the general lack of hydrogeologic data and uncertainties in water-budget components. Because of the limited data available for modeling, the model should be considered as only partially, or incompletely, calibrated. Despite this consideration, simulation results indicate that the aquifer may be able to provide a significant amount of water for public supply, and that additional ground-water development may be possible.

Additional data needed to more completely define the hydrologic system of the Aguadilla to Río Camuy area include information on hydraulic conductivity, saturated thickness of the aquifer, position of the freshwater/saline-water interface, location and discharge of onshore and offshore springs, continuous streamflow and water-level data, and ground-water use. No attempt was made to evaluate the storage properties of the aquifer by means of transient model calibrations, so that use of the model for analysis of transient ground-water problems would be inappropriate.

\section{REFERENCES}

Black and Veatch Consulting Engineers, 1971, Water resources of Puerto Rico, Phase II, Surface-water appraisal report, vol. 1.

Curtis, R.E., Jr., Aquino, Z., Díaz, P.L., and Vachíer, R.J., 1991, Water resources data-Puerto Rico and the U.S. Virgin Islands, Water Year 1990: U.S. Geological Survey Water-Data Report PR-90-1, 514 p.
Giusti, E.V., 1978, Hydrogeology of the karst of Puerto Rico: U.S. Geological Survey Professional Paper 1012, 68 p.

Gómez-Gómez, Fernando, 1987, Planning report for the Caribbean Islands regional aquifer-system analysis project: U.S. Geological Survey Water-Resources Investigations Report 86-4074, 50 p.

Gómez-Gómez, Fernando, and Torres-Sierra, Heriberto, 1988, Hydrology and effects of development on the water-table aquifer in the Vega Alta quadrangle, Puerto Rico: U.S. Geological Survey Water-Resources Investigations Report 87-4105, 54 p.

Guzmán-Ríos, Senén, 1988, Hydrology and water quality of the principal springs in Puerto Rico: U.S. Geological Survey Water-Resources Investigations Report 85-4269, 30 p.

Heisel, J.E., González, J.R., and Cruz, Carlos, 1983, Analog model analysis of the North Coast Limestone aquifers, Puerto Rico: U.S. Geological Survey Open-File Report $82-52,49 \mathrm{p}$.

Institute of Hydrology, 1980a, Low flow studies: Wallingford, Oxon, United Kingdom, Report no. 1, 21 p. 1980b, Low flow studies: Wallingford, Oxon, United Kingdom, Report no. 3, p. 12-19.

McDonald, M.G., and Harbaugh, A.W., 1988, A modular, three dimensional, finite-difference ground-water flow model: U.S. Geological Survey Techniques of WaterResources Investigations, book 6, chap. A1, 586 p.

Monroe, W.H., 1969, Geologic map of the Moca and Isabela quadrangles, Puerto Rico: U.S. Geological Survey Miscellaneous Geologic Investigations Map I-565. 1976, The karst landforms of Puerto Rico: U.S. Geological Survey Professional Paper 899, 69 p. 1980, Geology of the Middle Tertiary formations of Puerto Rico: U.S. Geological Survey Professional Paper 953, 93 p.

Percious, J.D., 1971, Submarine spring explorations-northwest coast of Puerto Rico: Water Resources Research Institute, University of Puerto Rico, Mayagüez Campus, School of Engineering, Final Report A-029-PR, 48 p.

Rodríguez-Martínez, Jesús, 1991, The hydrogeologic framework of the northern coastal province aquifer system of Puerto Rico, in Gómez-Gómez, Fernando, QuiñonesAponte, Vicente, and Johnson, A.I, eds., Aquifers of the Caribbean Islands: American Water Resources Association Monograph 15, p. 5-16.

Rodríguez-Martínez, Jesús, and Hartley, J.L., 1994, Geologic and hydrologic data collected at test holes NC-6 and NC-11 Hatillo and Isabela, northwestern Puerto Rico: U.S. Geological Survey Open-File Report 93-465, 39 p.

Searcy, J.K., 1959, Flow-duration curves, in Manual of hydrology-Part 2, Low-flow techniques: U.S. Geological Survey Water-Supply Paper 542-A, 33 p. 
Seiglie, G.A., and Moussa, M.T., 1984, Late OligocenePliocene transgressive-regressive cycles of sedimentation in northwestern Puerto Rico, in Schlee, J.S., Interregional unconformities and hydrocarbon accumulation: American Association of Petroleum Geologists Memoir 36, p. 89-98.

Theis, C.V., Brown, R.H., and Meyer, R.R., 1963, Estimating transmissivity of aquifers from the specific capacity of wells, in Bentall, Ray, Methods of determining permeability, transmissibility, and drawdown: U.S. Geological Survey Water-Supply Paper 1536-I, p. 331-341.

Torres-González, Arturo, 1983, Hydrologic study of the Río Camuy cave system, Puerto Rico: University of Puerto Rico unpublished masters thesis, $115 \mathrm{p}$. 1985 , Simulation of ground-water flow in the watertable aquifer near Barceloneta, Puerto Rico: U.S. Geological Survey Water-Resources Investigations Report 84-4113, 39 p.

Torres-González, Arturo, Aguilar, E., and Pannela, G., 1984, Geohydrology of the Río Camuy cave system in Puerto
Rico: University of Puerto Rico, Journal of Engineering Research, v. 1, July 1984, p. 124-184.

Torres-González, Arturo, and Wolansky, R.M., 1984, Planning report for the comprehensive appraisal of the ground-water resources of the north coast limestone area of Puerto Rico: U.S. Geological Survey Open-File Report 84-427, 32 p.

U.S. Department of Commerce, 1991, 1990 census of population and housing characteristics, Puerto Rico:

U.S. Department of Commerce, Economics and Statistics Administration, Bureau of Census, 1990-CHP1-53.

Ward, W.C., Sharlach, R.A., and Hartley, J.R., 1991, Controls on porosity and permeability in subsurface Tertiary carbonate rocks of northern Puerto Rico, in Gómez-Gómez, Fernando, Quiñones-Aponte, Vicente, and Johnson, A.I., eds., Aquifers of the Caribbean Islands: American Water Resources Association Monograph 15, p. 17-23. 